\title{
1 Airmass aging metrics derived from particle and other measurements near Fort Worth
}

2 B. Karakurt Cevik ${ }^{\mathrm{a}}$, A.P. Rutter ${ }^{\mathrm{a} 1}$, L. Gong ${ }^{\mathrm{a} 2}$, R.J. Griffin ${ }^{\mathrm{a}}$, J.H. Flynn ${ }^{\mathrm{b}}$, B.L. Lefer ${ }^{\mathrm{b} 3}$, and S.

$3 \mathrm{Kim}^{\mathrm{c} 4}$

$4 \quad{ }^{\mathrm{a}}$ Department of Civil and Environmental Engineering, Rice University, Houston, TX 77005

5 (bk4@rice.edu)

$6 \quad{ }^{1}$ Now at S.C. Johnson, Inc., Racine, WI 53403 (andrew.p.rutter@gmail.com)

$7 \quad{ }^{2}$ Now at California Air Resources Board, Sacramento, CA 95811 (Longwen.Gong@arb.ca.gov)

$8{ }^{\mathrm{b}}$ Department of Earth and Atmospheric Sciences, University of Houston, Houston, TX 77004

9 (jhflynn@uh.edu)

10 Now at NASA Headquarters, Washington, DC, 20546 (barry.lefer@nasa.gov)

$11{ }^{\mathrm{c}}$ Atmospheric Chemistry Division, National Center for Atmospheric Research, Boulder, CO

1280307

$13{ }^{4}$ Now at Department of Earth System Science, University of California, Irvine, CA 92697

14 (saewungk@uci.edu)

15 *Correspondence: rob.griffin@rice.edu; ph: 713-348-2093; fax: 713-348-5268

16 


\section{Highlights}

18 - $\mathrm{OA} / \Delta \mathrm{CO}$ and aging metrics for hydrocarbons and $\mathrm{NO}_{\mathrm{x}}$ are correlated

$19-\mathrm{OA} / \Delta \mathrm{CO}$ is not correlated to a sulfur aging metric

20 - More rapid OA enhancement is observed with lower values of the $\mathrm{NO}_{\mathrm{x}}$ aging metric

21 Increasing $\mathrm{OA} / \Delta \mathrm{CO}$ with photochemical age is valid only up to approximately 30 hours 


\section{Abstract}

The composition, concentration, and size of submicron particulate matter $\left(\mathrm{PM}_{1}\right)$ were

25 measured at five-minute resolution by an Aerodyne high-resolution time-of-flight aerosol mass

26 spectrometer (HR-ToF-AMS) at a semi-rural location northwest of the Dallas-Fort Worth, TX,

27 area during June 2011. Because of increased organic aerosol (OA) levels, focus here is placed on

28 the period from June 17-30. The total measured $\mathrm{PM}_{1}$ mass concentration ranged between 1.1 and

$2916.5 \mu \mathrm{g} \mathrm{m}^{-3}$, with a mean of $4.4 \pm 2.6$ (one s.d.) $\mu \mathrm{g} \mathrm{m}^{-3}$. Significant variability is observed in the

30 time series of total $\mathrm{PM}_{1}$ and of four individual HR-ToF-AMS species, particularly between June

3121 and 25 . The average $\mathrm{PM}_{1}$ composition was dominated by $\mathrm{OA}(55.0 \pm 14.8 \%)$ and sulfate

$32(30.7 \pm 12.3 \%)$. Organic aerosol concentrations were correlated positively with carbon monoxide

$33(\mathrm{CO})(\mathrm{R}=0$.81). This study uses a variety of aging metrics and their relations to $\mathrm{OA} / \Delta \mathrm{CO}$ to

34 characterize secondary organic aerosol. Photochemical age is estimated by using the toluene to

35 benzene ratio. The average photochemical age was $26.7 \pm 5.3$ hours. Other metrics of age used

36 in this work include the ratio of sulfate to total sulfur and the ratio of nitrogen oxides to total

37 reactive nitrogen. The correlations between the $\mathrm{OA} / \Delta \mathrm{CO}$ and nitrogen aging metrics indicate

38 consistent aging. However, the relationship between photochemical age and $\mathrm{OA} / \Delta \mathrm{CO}$ shows a

39 peak at approximately 30 hours, which could be indicative of dilution by air with high levels of

$40 \mathrm{CO}$ or of reaching a point in time at which further oxidation leads to a decrease in aerosol mass

41 due to material repartitioning to the gas phase.

42 Keywords: organic aerosol; photochemical age; Fort Worth 


\section{Introduction}

Despite established National Ambient Air Quality Standards, high concentrations of

46 particulate matter (PM) still occur in some regions of the United States. The presence of PM in

47 the troposphere impacts climate, visibility, and public health. Aerosols affect Earth's climate

48 directly by scattering (cooling effect) or absorbing (warming effect) radiation, and they can serve

49 as condensation and ice nuclei for cloud formation, leading to indirect climate impacts (Forster et al., 2007). Aerosols cause visibility reduction through the extinction of visible light. Elevated

51 concentrations of PM also have been correlated strongly to increased rates of human respiratory

52 and allergic illnesses and death (Pope et al., 2002).

Organic aerosol (OA) accounts for a large fraction of atmospheric fine PM and can be

55 atmosphere from natural or anthropogenic sources and secondary OA (SOA) that is formed in

56 the atmosphere through the oxidation of natural or anthropogenic volatile organic compounds

57 (VOCs) and subsequent partitioning of the products (Zhang et al., 2007). Although the

58 importance of aerosols in climate, visibility, and public health is well known, the quantification

59 of these impacts includes significant uncertainties because of deficiencies in the understanding of

60 the sources, formation mechanisms, and aging processes associated with SOA (Jimenez et al.,

$612009)$

62 A temporary ground-based photochemical "supersite" was established at the Eagle Mountain

63 Lake (EML) Texas Commission on Environmental Quality (TCEQ) monitoring site in the

64 Dallas-Fort Worth (DFW) area during June 2011. The goal of the campaign was to investigate

65 the influence that oil and natural gas operations in this area have on local air quality. As part of

66 this, PM measurements were made to help differentiate locally emitted and transported POA and 
67 SOA. This specific work describes efforts to investigate relationships between enhanced OA

68 concentrations and aging processes at the site. Organic aerosol data were analyzed in the context

69 of OA enhancements with respect to excess carbon monoxide (CO), the ratio of which can be

70 used to investigate the relative importance of SOA (DeCarlo et al., 2010; Hayes et al., 2013).

71 Photochemical age estimated from toluene to benzene ratios, the ratio of sulfate $\left(\mathrm{SO}_{4}{ }^{2-}\right)$ to total

72 sulfur, and the ratio of nitrogen oxides $\left(\mathrm{NO}_{\mathrm{x}}=\right.$ nitric oxide $(\mathrm{NO})$ plus nitrogen dioxide $\left.\left(\mathrm{NO}_{2}\right)\right)$ to

73 total reactive nitrogen $\left(\mathrm{NO}_{\mathrm{y}}\right)$ also were used as airmass age indicators to help characterize

74 processes relevant to $\mathrm{OA}$ at the site and to allow comparison between various metrics of age.

75

\section{Experimental}

\subsection{Sampling site and meteorology}

Measurements were performed continuously in June 2011 at the EML TCEQ monitoring site, which is located $226 \mathrm{~m}$ above sea level, in Fort Worth, TX, at $32^{\circ} 59^{\prime} 16^{\prime \prime} \mathrm{N}, 97^{\circ} 28^{\prime} 37^{\prime \prime} \mathrm{W}$.

Due to increased pollution levels, only the second half of the month is considered in this study.

The site is in a semi-rural area and is $\sim 40 \mathrm{~km}$ northwest of downtown Fort Worth. The combined DFW area is the largest metropolitan area in Texas and the fourth largest metropolitan area in the United States, with a population of approximately 6.5 million people. The site is flat and includes various grasses and shrubs. It is located a few kilometers west of a minor state highway and near abundant natural gas and oil operations. The land on which the site sits is owned by the United States National Guard and is used as rangeland for cattle.

Meteorology is described in detail in Rutter et al. (2015); a brief overview is given here. During the campaign, the wind speed and direction were fairly stable. The average wind speed was $7.9 \mathrm{~m} \mathrm{~s}^{-1}$, and the wind direction was almost continuously southerly and southeasterly 
90 throughout the campaign, which placed the site downwind of the DFW metropolitan area. There

91 was thunderstorm activity during the night of June 21, which was the only time during the

92 campaign with measureable precipitation. The temperature varied from 17.7 to $39.6{ }^{\circ} \mathrm{C}$, and the

93 relative humidity $(\mathrm{RH})$ ranged from $13.8 \%$ to $93.3 \%$ during the sampling time. Temperature and

94 RH each varied diurnally. Days were generally cloud-free.

$95 \quad 2.2$ Instrumentation

96 Particles were sampled from a main copper tubing inlet. An Aerodyne high-resolution time-

97 of-flight aerosol mass spectrometer (HR-ToF-AMS) and a Brechtel Manufacturing, Inc. (BMI)

98 particle-into-liquid sampler (PILS) connected to Dionex ion chromatographs (IC) subsampled

99 from the main inlet, which was equipped with a $2.5-\mu \mathrm{m}$ cyclone. The main inlet extended

100 approximately $5 \mathrm{~m}$ above ground level. Rutter et al. (2015) describe instrumentation in more

101 detail so overviews of only the HR-ToF-AMS and PILS are given here.

102 The HR-ToF-AMS (DeCarlo et al., 2006) is an online measurement of size-resolved

103 chemistry of submicron non-refractory atmospheric aerosol. Air is sampled through a critical

104 orifice and enters an aerodynamic lens that forces particles to focus into a narrow beam that is

105 accelerated into a vacuum chamber. The size of the particle is measured by particle time of flight

106 (PToF) through this region. After the particles pass through the PToF region, they are vaporized

107 after impacting on a heated surface $\left(600^{\circ} \mathrm{C}\right)$; vaporized material is ionized by electron impact.

108 The resultant ions are detected by a time-of-flight mass spectrometer and attributed to specific

109 aerosol species (sulfate, nitrate, chloride, ammonium, and organic material) based on their mass-

110 to-charge $(\mathrm{m} / \mathrm{z})$ ratios. Based on spectral characteristics, organic material is attributed to various

111 types of OA including hydrocarbon-like OA (HOA, thought to be a proxy for combustion-

112 derived POA) and various types of oxidized OA (OOA), thought to be proxies for SOA or 
113 processed POA (Zhang et al., 2005; Jimenez et al., 2009; Ulbrich et al., 2009; Huang et al.,

114 2010). In this case, LV-OOA (termed OOAI in previous studies) represents the factor that

115 exhibits a greater extent of oxidation, and SV-OOA (termed OOAII in previous studies) is that

116 which is less oxidized. As a proxy for SOA mass concentration, pSOA is calculated as the sum

117 of LV-OOA and SV-OOA.

118 The PILS provides an online measurement of water-soluble ionic aerosol chemical

119 composition at a resolution of 16 minutes. The PILS collects particles by growing them through

120 exposure to a saturated steam environment and then causing their impaction on a surface. A

121 solution containing aerosol species for injection to the ICs (Dionex ICS 1600) is generated by

122 washing the impaction surface with deionized water (Weber et al., 2001; Orsini et al., 2003). A

123 BMI, Inc. Model 8003 impactor was used to remove particles with diameters larger than 1

124 micron. Sulfate ion concentrations measured with the PILS-ICs are used to determine the

125 collection efficiency of the HR-ToF-AMS. All data shown have been corrected for this assumed 126 constant efficiency of $69 \%$.

127 Gas-phase species were sampled from separate inlets attached to a walk-up scaffold that

128 reached approximately $20 \mathrm{~m}$ above ground level. Except for the VOC measurements, trace gases

129 were sampled through a common $1 / 4$ " stainless steel tube from which instruments subsampled.

130 The VOC inlet required 1/4" PFA tubing. A Thermo Electron Corp. (TECO) 48C Trace Level

$131 \mathrm{CO}$ Analyzer (gas filter correlation), a TECO 42C Trace Level nitrogen oxide ( $\mathrm{NO}$ and $\mathrm{NO}_{2}$ )

132 Analyzer (chemiluminescence), a TECO $42 \mathrm{C}-\mathrm{Y}$ total reactive nitrogen $\left(\mathrm{NO}_{\mathrm{y}}\right)$ Analyzer

133 (molybdenum converter), a TECO 49C ozone $\left(\mathrm{O}_{3}\right)$ Analyzer (ultraviolet), a TECO 43C Trace

134 Level sulfur dioxide $\left(\mathrm{SO}_{2}\right)$ Analyzer (Pulsed Fluorescence), and an IONICON Analytik Proton

135 Transfer Reaction-Time of Flight- Mass Spectrometer (PTR-ToF-MS) were deployed to measure 
136 trace gases including $\mathrm{CO}, \mathrm{NO}_{2}, \mathrm{NO}, \mathrm{NO}_{\mathrm{y}}, \mathrm{O}_{3}, \mathrm{SO}_{2}$, and VOCs, respectively. Meteorological data

137 including planetary boundary layer height, temperature, wind speed, and wind direction were

138 tracked with a Vaisala DigiCORA tethersonde system, a Campbell Scientific HMP45C platinum

139 resistance thermometer, and a Campbell Scientific 05103 R. M. Young wind monitor.

\section{Results and Discussion}

\section{1 $\mathrm{PM}_{1}$ overview}

The total observed HR-ToF-AMS $\mathrm{PM}_{1}$ mass concentration ranged between 1.1 and $16.5 \mu \mathrm{g}$

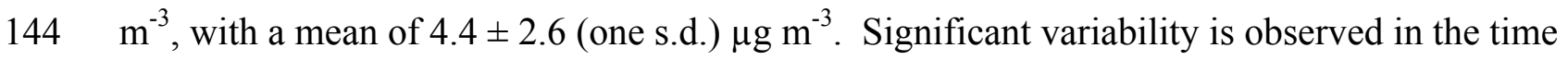

145 series of total $\mathrm{PM}_{1}$ and of all species (Figure S1). The average aerosol composition was

146 dominated by organic matter $(55.0 \pm 14.8 \%)$ and sulfate $(30.7 \pm 12.3 \%)$, followed by smaller

147 contributions from ammonium $(10.7 \pm 3.8 \%)$, and nitrate $(3.1 \pm 1.5 \%)$. Over the campaign, the

148 average sulfate mass concentration was $1.2 \pm 0.8 \mu \mathrm{g} \mathrm{m}^{-3}$, with a range of 0.2 to $6.7 \mu \mathrm{g} \mathrm{m}^{-3}$. The

149 rapid increase in the sulfate concentration on the night of June 24 also is observed in $\mathrm{SO}_{2}$ mixing

150 ratios and particle number concentrations (not shown) (Figure S2). The time series of ammonium

151 and sulfate are well correlated $(\mathrm{R}=0.98$, Figure $\mathrm{S} 3)$, indicating the predominance of ammonium

152 sulfate relative to ammonium nitrate. This is expected due to the high temperatures during the

153 sampling period and indicates the general aged quality of the inorganic aerosol.

154 Large spikes in concentrations are observed, particularly between June 21 and 25. The large

155 spikes are mostly driven by increases in OA. The average OA concentration was $2.6 \pm 1.9 \mu \mathrm{g} \mathrm{m}^{-}$

$15{ }^{3}$, with a wide range of 0.3 to $12.8 \mu \mathrm{g} \mathrm{m}^{-3}$. Organic aerosol was correlated positively with $\mathrm{CO}$,

157 likely indicating a relationship between $\mathrm{OA}$ and combustion activities $(\mathrm{R}=0.81)$. 
The mean OA concentration diurnal profile (Figure 1) during daytime shows a slight increase starting from $1030 \mathrm{CST}$ to $1830 \mathrm{CST}$, likely as a result of photochemical processing, with the diurnal profile more pronounced for median values. The ratios of the mean to the median OA concentrations are closer to unity between 1000 CST to 1600 CST, indicating significant

163 diurnal profile, significant attention is paid to OA here.
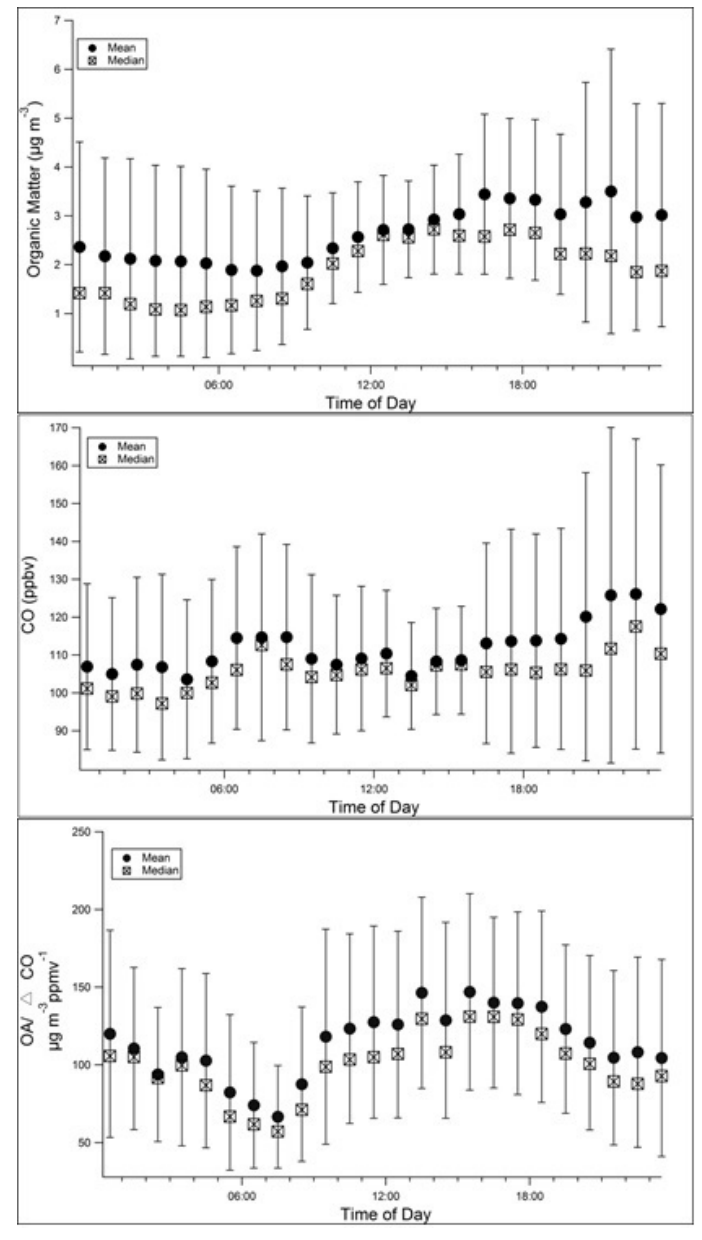

165 Figure 1. Diurnal profile plots of OA $\left(\mu \mathrm{g} \mathrm{m}^{-3}\right), \mathrm{CO}(\mathrm{ppbv})$, and OA/ $\Delta \mathrm{CO}\left(\mu \mathrm{g} \mathrm{m}^{-3} \mathrm{ppmv}^{-1}\right)$. The points in the middle 166 show the mean (solid) and median, and the bottom and the top of the whiskers represent the 25th and 75th 167 percentiles, respectively.

\subsection{OA Characterization}

Both $\mathrm{O}_{3}$ and the quantity $\mathrm{O}_{\mathrm{x}}\left(\mathrm{O}_{\mathrm{x}}=\mathrm{O}_{3}+\mathrm{NO}_{2}\right)$ are driven photochemically. However, $\mathrm{O}_{\mathrm{x}}$ is a 
172 eventually reproduces $\mathrm{O}_{3}$. Previous studies have reported correlation between $\mathrm{O}_{3}$ and pSOA

173 during periods of pSOA formation due to both requiring photochemical oxidation (Cabada et al.,

174 2004; Liu et al., 2011). The positive correlation between $\mathrm{O}_{\mathrm{x}}$ and $\mathrm{pSOA}$ also has been reported in

175 air masses affected on relatively short timescales (less than eight hours) and with no significant

176 local $\mathrm{NO}_{2}$ sources (Herndon et al., 2008; Wood et al., 2010).

177 The times series for $\mathrm{pSOA}, \mathrm{O}_{3}$, and $\mathrm{O}_{\mathrm{x}}$ track each other well for the DFW campaign.

178 Correlation coefficients $(\mathrm{R})$ are 0.64 and 0.71 for $\mathrm{O}_{3}$ and $\mathrm{O}_{\mathrm{x}}$, respectively, with pSOA (Figure 2).

179 The correlation of pSOA with $\mathrm{O}_{3}$ and $\mathrm{O}_{\mathrm{x}}$ confirms photochemically driven SOA formation.
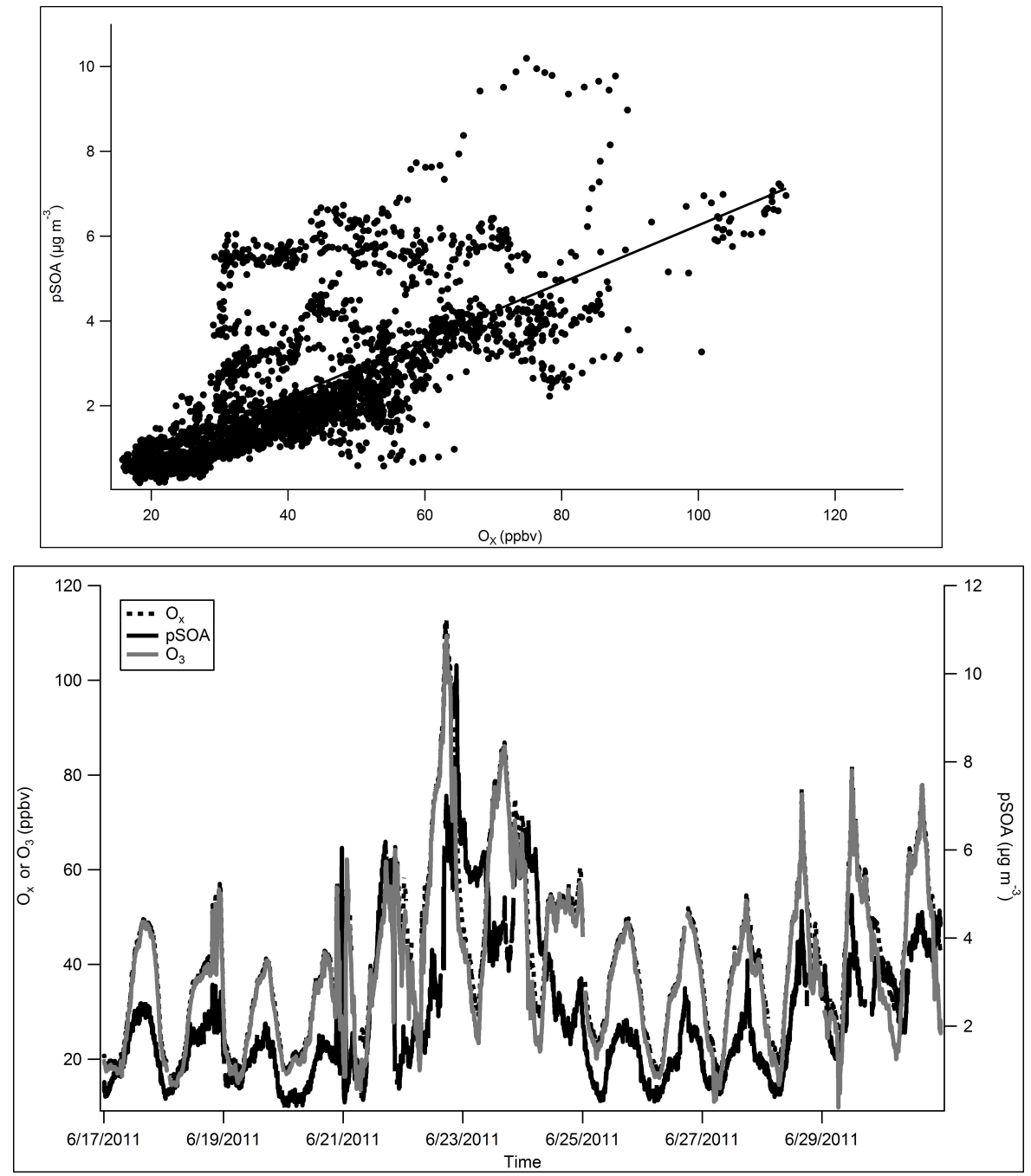

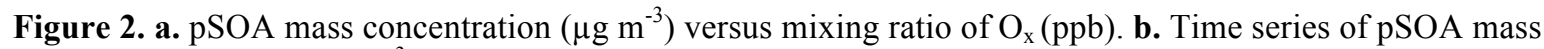
concentration (black, $\mu \mathrm{g} \mathrm{m}^{-3}$ ), mixing ratio of $\mathrm{O}_{\mathrm{x}}$ (dashed, ppbv), and mixing ratio of $\mathrm{O}_{3}$ (gray, ppbv). 
The O:C and $\mathrm{H}: \mathrm{C}$ elemental ratios of ambient $\mathrm{OA}$ can be estimated by summation of the contribution of each element within each ion (Aiken et al., 2008). The average of O:C is $0.5 \pm$

1860.1 and reaches a value up to 0.9 ; the average value of $\mathrm{H}: \mathrm{C}$ is $1.3 \pm 0.1$. The van Krevelen

187 diagram (H:C versus O:C) indicates the oxidation mechanisms of relevance to the OA. Slopes of

$188-2,-0.5$, and 0 correspond to the addition of ketone/aldehyde, carboxylic acid, and

189 alcohol/peroxide groups to an aliphatic (unfunctionalized) carbon, respectively (Heald et al.,

190 2010). The slope of $H: C$ versus O:C for DFW is $-0.6(R=0.7)$; this slope falls between those for

191 ketone/aldehyde and carboxylic acid but closer to that for carboxylic acid (Figure S4). It should

192 be noted that the slope on the diagram can be a result of different combinations of reactions;

193 therefore, the slope only gives information on the range of oxidation processes that are

194 responsible for the aging of the OA. Slopes of ambient data usually range between -0.5 to -1 . The 195 slope observed in DFW is similar to those observed in Pasadena, CA (-0.64) (Hayes et al., 2013)

196 and Changdao, China (-0.63) (Hu et al., 2013).

197 Carbon oxidation state (OSc $=2 * \mathrm{O}: \mathrm{C}-\mathrm{H}: \mathrm{C})$ describes the extent of OA processing and 198 usually ranges between -2 to +1 for observed OA (Kroll et al., 2011). Lower OS represents 199 HOA (between -1.7 to -1.6), while OOA typically has an $\mathrm{OS}_{\mathrm{c}}$ between -0.5 to +0.9 (Kroll et al., 200 2011). In this dataset most of the OSc values fall between -0.5 and +0.5 , with a mean of -0.2 . 201 The mean and median values are close to each other, which suggests relatively little impact of 202 events characterized by atypical levels of either type of OA. Figure S5 shows the diurnal profile 203 of $\mathrm{OS}_{\mathrm{c}}$ values. $\mathrm{OS}_{\mathrm{c}}$ starts increasing in the morning at $830 \mathrm{CST}$ and shows a decrease after 1930 204 CST suggesting a higher oxidation state during daytime, as expected. 


\subsection{OA/ $\Delta$ CO Analysis}

Analysis of the ratio of $\mathrm{OA}$ to $\mathrm{CO}$ has been used previously to investigate the aging and

207 formation of SOA (Kleinman et al., 2008; DeCarlo et al., 2010; Hayes et al., 2013). Carbon

208 monoxide is a fairly conservative pollutant with a lifetime with respect to hydroxyl radical $(\mathrm{OH})$

209 oxidation on the order of two months. Therefore, any dilution effect on the time scale of hours to

210 days can be minimized by analyzing the ratio of OA to CO (Hodzic and Jimenez, 2011).

211 Because CO and POA generally have similar emission sources, their concentration ratios are

212 expected to be somewhat constant in a source region over a short timeframe (Hodzic and

213 Jimenez, 2011). Consequently, any increases in the ratio of OA to $\Delta \mathrm{CO}$ (measured CO minus

214 background $\mathrm{CO}$ ) can be used as an indicator of SOA formation.

215 To calculate the $\mathrm{OA} / \Delta \mathrm{CO}\left(\mu \mathrm{g} \mathrm{m}^{-3} \mathrm{ppmv}^{-1}\right)$ ratio, the fifth percentile of $\mathrm{CO}$ mixing ratio

216 (ppmv) is used as a background level (0.085 ppmv) and subtracted from measured values in this

217 study (Cottrell et al., 2008). Fifth and $95^{\text {th }}$ percentiles of OA/ $\Delta C O$ values were calculated, and

218 any values smaller or larger than those values were removed.

219 OA mass concentrations and CO mixing ratios generally track each other (Figure 3). A

220 diurnal trend can be observed in OA time series, except the period with large spikes between

221 June 21 and 25. The $\mathrm{OA} / \Delta \mathrm{CO}$ time series shows greater variability than the individual OA and

222 CO time series, with lower values between June 21 and June 25 despite both species being

223 enhanced.

224 The average $\mathrm{OA} / \Delta \mathrm{CO}$ in the DFW region was $113.9 \pm 60.8 \mu \mathrm{g} \mathrm{m}^{-3} \mathrm{ppmv}^{-1}$, with a range of

22523.9 and $346.9 \mu \mathrm{g} \mathrm{m}^{-3} \mathrm{ppmv}^{-1}$ (Table 1). Figure 1 shows a diurnal profile of the ratio, along with

226 diurnal profiles of OA and CO alone. Organic aerosol enhancement with respect to CO starts in

227 the morning (increased photochemical activity) at 830 CST and shows a decrease after sunset 
$2281830 \mathrm{CST}$. However, values remain relatively consistent overnight. If the premise of this

229 approach regarding co-location of $\mathrm{CO}$ and POA emissions is correct, this consistency at night

230 potentially can be explained by OA formation at night to counter particle deposition and

231 enhancement of $\mathrm{CO}$ in the shallower nocturnal boundary layer. An increase of OOA/ $\Delta \mathrm{CO}$ at

232 night was observed during a field campaign in Houston in 2006 (Cleveland et al., 2012). The CO

233 diurnal profile shows its first peak during morning rush hour between 0530 CST and 0930 CST,

234 starts increasing at $1430 \mathrm{CST}$, keeps increasing until midnight, and then remains low.
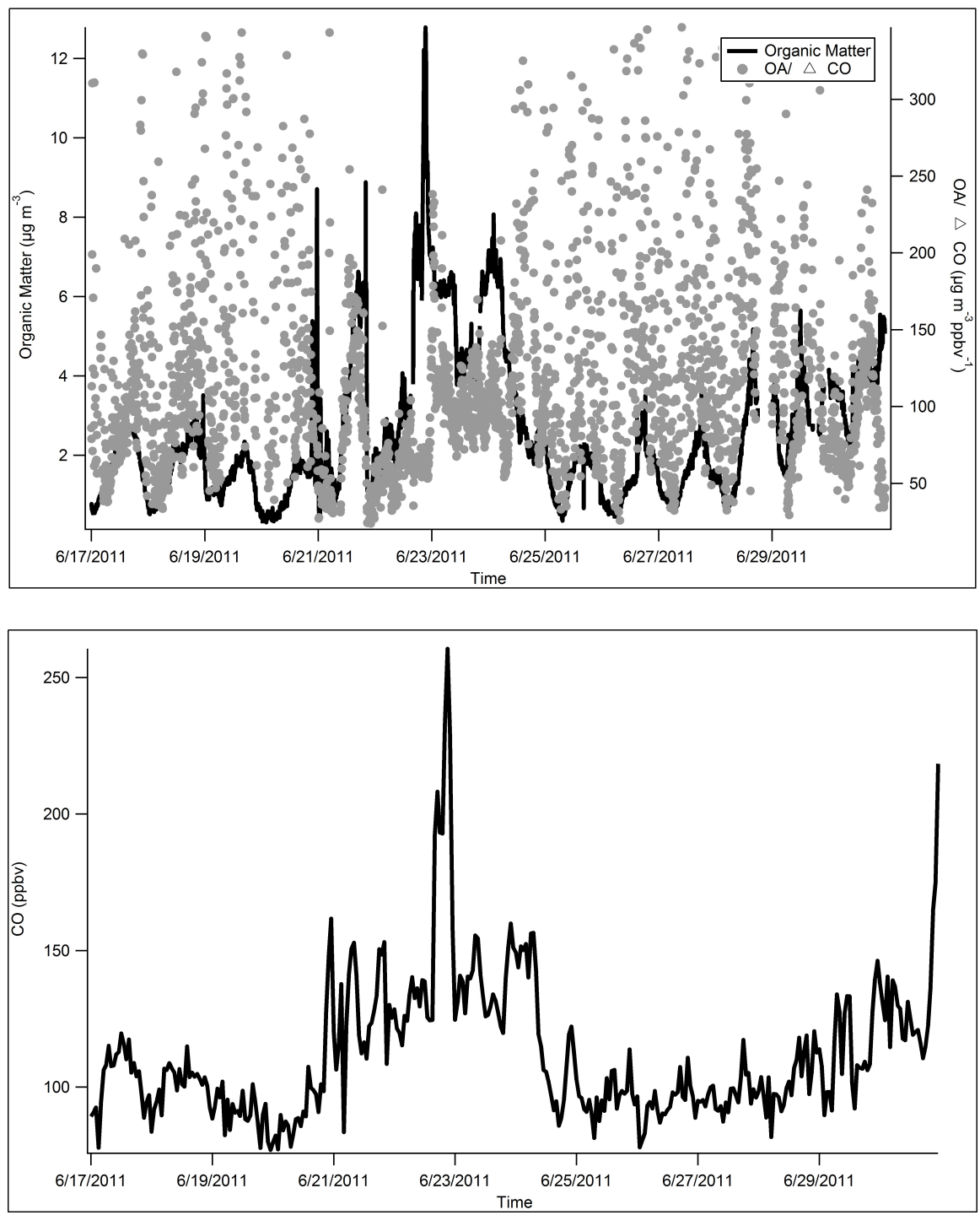

Figure 3. Time series of $\mathrm{OA} / \Delta \mathrm{CO}$ (gray, $\mu \mathrm{g} \mathrm{m}^{-3} \mathrm{ppmv}^{-1}$ ), mass concentrations of $\mathrm{OA}$ (black, $\mu \mathrm{g} \mathrm{m}^{-3}$ ), and the mixing ratio of $\mathrm{CO}$ (ppbv). 
Table 1. Statistics of $\mathrm{OA} / \Delta \mathrm{CO}$ and other aging metrics.

\begin{tabular}{lllll}
\hline & $\mathbf{O A} / \Delta \mathbf{C O}\left(\boldsymbol{\mu g ~ \mathbf { ~ m } ^ { - 3 }} \mathbf{p p m v}{ }^{-1}\right)$ & $-\log \left(\mathbf{N O}_{\mathbf{x}} / \mathbf{N O}_{\mathbf{y}}\right)$ & $\left.\mathbf{S O}_{\mathbf{4}}{ }^{2-} / \mathbf{S O}_{\mathbf{2}}+\mathbf{S O}_{\mathbf{4}}{ }^{2-}\right)$ & Photochemical Age $(\mathbf{h r})$ \\
\hline Mean & 113.9 & 0.3 & 0.6 & 26.7 \\
Median & 99.9 & 0.3 & 0.7 & 26.9 \\
Std Dev & 60.8 & 0.2 & 0.1 & 5.3 \\
Std Error & 1.1 & 0.0 & 0.0 & 0.2 \\
Min & 23.9 & 0.0 & 0.4 & 13.9 \\
Max & 346.9 & 0.8 & 0.8 & 38.1 \\
\hline
\end{tabular}

\subsection{Airmass Aging Metrics}

Photochemical age and other aging surrogates were used to evaluate the extent of processing

243 and for intercomparison in the DFW area. It is important to note that these values are only

244 approximations/proxies of the airmass age because the calculation of the real age is more

245 complicated, requires reaction rates and oxidant levels, and depends on atmospheric conditions.

246 However, it should be noted that all metrics presented here are expected to increase with airmass

247 aging. In addition, it is hypothesized that relationships between $\mathrm{OA} / \Delta \mathrm{CO}$ and any of these age

248 metrics may allow insight into processes relevant for pSOA. An error and statistical analysis is

249 presented in the supplemental information.

\subsubsection{Sulfur}

The processing of the observed airmasses with respect to $\mathrm{SO}_{2}$ is calculated by the ratio of

252 sulfate from the HR-ToF-AMS to total sulfur (assuming sulfate and $\mathrm{SO}_{2}$ constitute total sulfur),

$253 \mathrm{SO}_{4}{ }^{2-} /\left(\mathrm{SO}_{4}{ }^{2-}+\mathrm{SO}_{2}\right)$, because over time emitted $\mathrm{SO}_{2}$ is oxidized to sulfuric acid which then forms

$254 \mathrm{SO}_{4}{ }^{2-}$ (Quinn et al., 2005). The photochemical age is expected to increase with the increase in the

255 ratio of $\mathrm{SO}_{4}{ }^{2-} /\left(\mathrm{SO}_{4}{ }^{2-}+\mathrm{SO}_{2}\right)$. Because sulfur is predominantly emitted from coal-burning power

256 plants, this aging metric is similar to the concept of plume age (Springston et al., 2005). 
The $\mathrm{SO}_{4}{ }^{2-} /\left(\mathrm{SO}_{4}{ }^{2-}+\mathrm{SO}_{2}\right)$ values range between 0.4 and 0.8 , and no significant diurnal profile 258 is observed. The average sulfate aging metric is $0.6 \pm 0.1$ (Table 1). The observed sulfate aging 259 metric values were comparable to those measured in Ontario, Canada (Hayden et al., 2011).

260 Figure 4a shows the time series of $\mathrm{OA} / \Delta \mathrm{CO}$ as a function of the sulfate aging metric. Most

$261 \mathrm{SO}_{4}{ }^{2-} /\left(\mathrm{SO}_{4}{ }^{2-}+\mathrm{SO}_{2}\right)$ data fall near the average value, and no consistent monotonic linear

262 relationship between the $\Delta \mathrm{OA} / \Delta \mathrm{CO}$ values and the sulfate aging metric can be observed (Figure

263 4a). As illustrated Figure 4b, overall only a very slight positive correlation can be observed

264 between the two metrics when $\mathrm{OA} / \Delta \mathrm{CO}$ values are averaged within binned values of the sulfur

265 aging metric. This suggests that processing mechanisms required for sulfate formation likely

266 contribute to enhancements in OA indirectly by altering the nature of the aerosol. The poor

267 correlation also can be explained by the relatively long lifetimes of $\mathrm{SO}_{2}$ with respect to aqueous-

268 and gas-phase oxidation, which are approximately 70 hours and 7 days, respectively (Wojcik and 269 Chang, 1997). The sulfur aging metric therefore does not reflect more local processes.

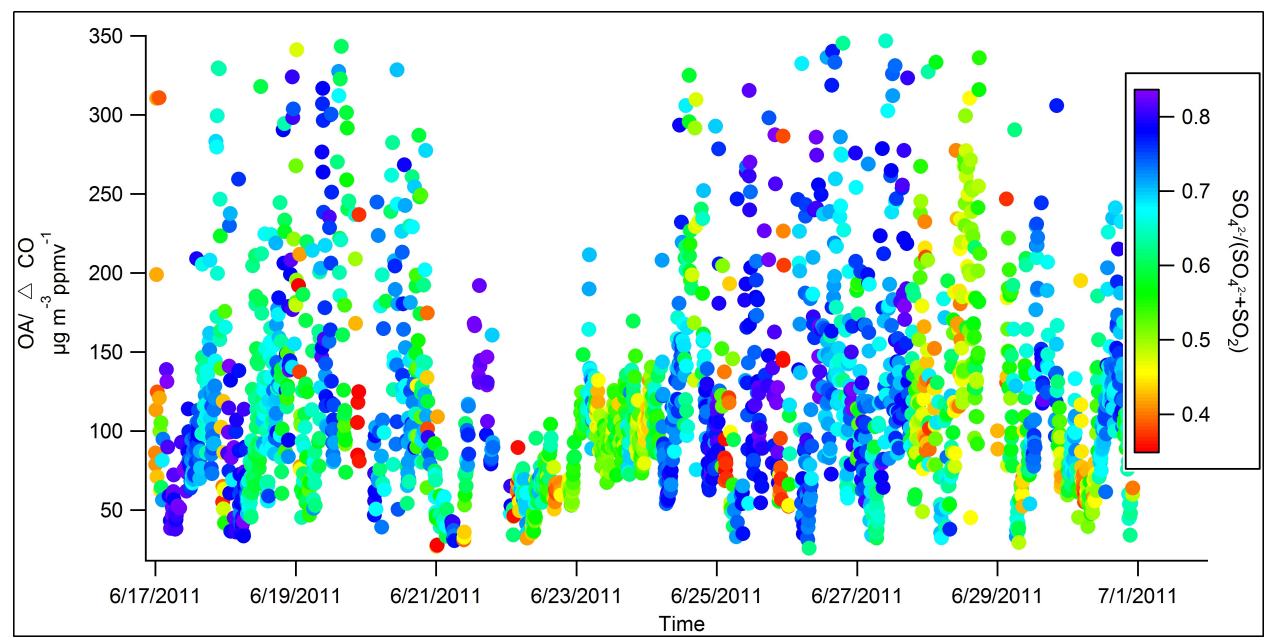




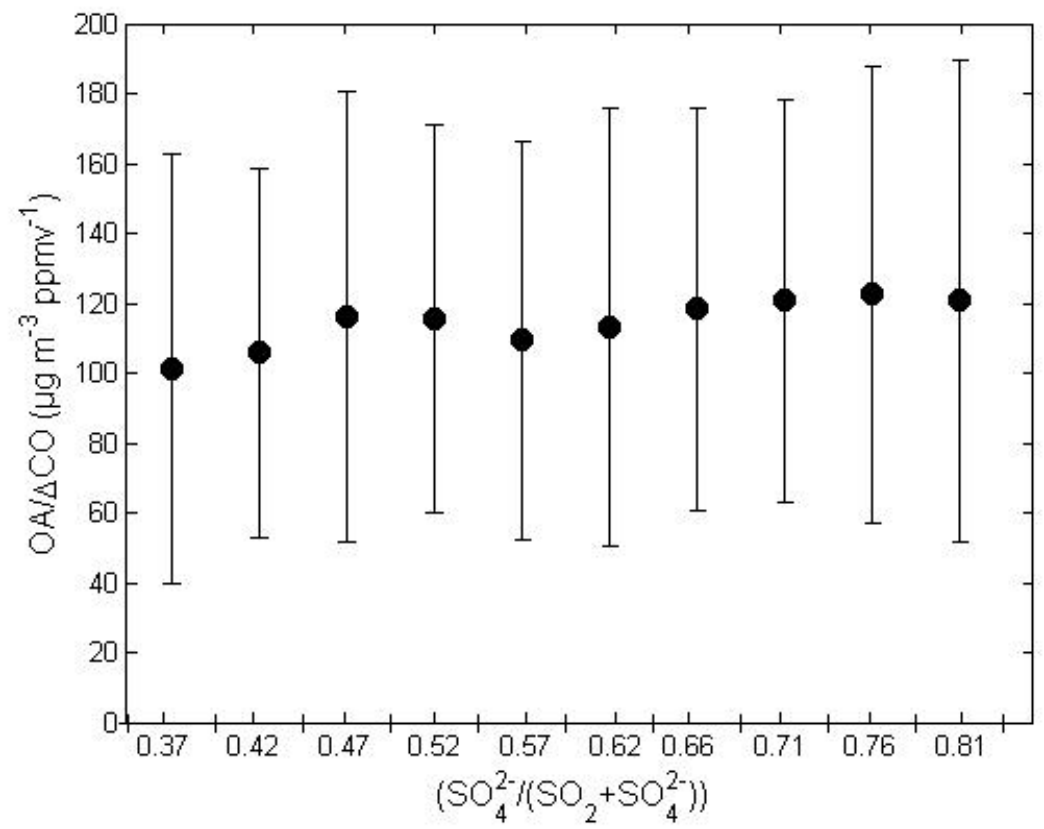

Figure 4. a.) $\mathrm{OA} / \Delta \mathrm{CO}\left(\mu \mathrm{g} \mathrm{m}^{-3} \mathrm{ppmv}^{-1}\right)$ ratios color coded by $\mathrm{SO}_{4}{ }^{2-} /\left(\mathrm{SO}_{2}+\mathrm{SO}_{4}{ }^{2-}\right)$ b. $) \mathrm{OA} / \Delta \mathrm{CO}\left(\mu \mathrm{g} \mathrm{m}^{-3} \mathrm{ppmv}^{-1}\right)$ vs. $\left(\mathrm{SO}_{4}{ }^{2-} /\left(\mathrm{SO}_{2}+\mathrm{SO}_{4}{ }^{2-}\right)\right.$. The $\mathrm{OA} / \Delta \mathrm{CO}$ ratios are averaged into 10 bins according to $\mathrm{SO}_{4}{ }^{2-} /\left(\mathrm{SO}_{2}+\mathrm{SO}_{4}{ }^{2-}\right)$. The lack of data points that approach zero for the $x$-axis indicates consistently aged air with respect to sulfur. Error bars show the range of data.

\subsection{2 $\mathrm{NO}_{\mathrm{x}} / \mathrm{NO}_{\mathrm{y}}$}

The processing of the airmass with respect to $\mathrm{NO}_{\mathrm{x}}$ is approximated with the value of $-\log$ $\left(\mathrm{NO}_{\mathrm{x}} / \mathrm{NO}_{\mathrm{y}}\right)$. Nitrogen oxides, which are emitted mostly by fossil fuel combustion, are oxidized to species such as nitric acid, nitrous acid, nitrate radical, dinitrogen pentoxide, peroxynitric acid, and peroxyacetylnitrate (and its analogs) as the air is processed photochemically. Because $\mathrm{NO}_{\mathrm{y}}$

282 includes both $\mathrm{NO}_{\mathrm{x}}$ and all of its oxidation products, photochemical age increases with the increase of $-\log \left(\mathrm{NO}_{\mathrm{x}} / \mathrm{NO}_{\mathrm{y}}\right)$ ratio, and smaller values represent fresh emissions (Kleinman et al., 2007; DeCarlo et al., 2008; Slowik et al., 2011). For fresh emissions, $-\log \left(\mathrm{NO}_{\mathrm{x}} / \mathrm{NO}_{\mathrm{y}}\right)=0$, and when $\mathrm{NO}_{\mathrm{x}}$ is $10 \%$ of $\mathrm{NO}_{\mathrm{y}},-\log \left(\mathrm{NO}_{\mathrm{x}} / \mathrm{NO}_{\mathrm{y}}\right)=1($ Kleinman et al., 2008). This metric represents aging with respect to a combustion source. 
289 decreasing overnight. The average metric value was $0.3 \pm 0.2$ (Table 1 ). The observed -

$290 \log \left(\mathrm{NO}_{\mathrm{x}} / \mathrm{NO}_{\mathrm{y}}\right)$ values were similar to those observed by Slowik et al. (2011) in southwestern

291 Ontario and smaller than those observed by Kleinman et al. (2007) in New England. The time

292 series of $\mathrm{NO}_{\mathrm{x}}$ and $\mathrm{NO}_{\mathrm{y}}$ (Figure $\mathrm{S} 6$ ) are included as supplementary information.

293 Figure 5a shows the same OA/ $\Delta \mathrm{CO}$ time series but colored by the aging metric with respect

294 to $\mathrm{NO}_{\mathrm{x}}$. As illustrated in Figure 5a, values smaller than 0.2 are more likely when low $\mathrm{OA} / \Delta \mathrm{CO}$

295 ratios are observed; accordingly, values higher than 0.4 mostly correspond to higher $\mathrm{OA} / \Delta \mathrm{CO}$

296 values. This is intuitive as one would expect less OA enhancement in fresher airmasses. A

297 significant positive correlation exists between $-\log \left(\mathrm{NO}_{\mathrm{x}} / \mathrm{NO}_{\mathrm{y}}\right)$ and $\mathrm{OA} / \Delta \mathrm{CO}$ (Figure $5 \mathrm{~b}$ ), but the

298 slope of this relationship changes when $-\log \left(\mathrm{NO}_{\mathrm{x}} / \mathrm{NO}_{\mathrm{y}}\right)$ lies between 0.2 and 0.3 . A steeper

299 slope indicates that enhancement in OA occurs more rapidly as the airmass ages; a more gentle

300 slope indicates slower OA enhancement as the airmass ages. The larger slope in this case occurs

301 with fresher airmass age, likely signifying that OA processing and formation are more rapid in

302 fresher airmasses. Compared to the sulfur aging metric, the $\mathrm{NO}_{\mathrm{x}}$ aging metric is more likely to

303 reflect local processes. Kleinman et al. $(2007,2008)$ observed similar trends in New England

304 and Mexico City.

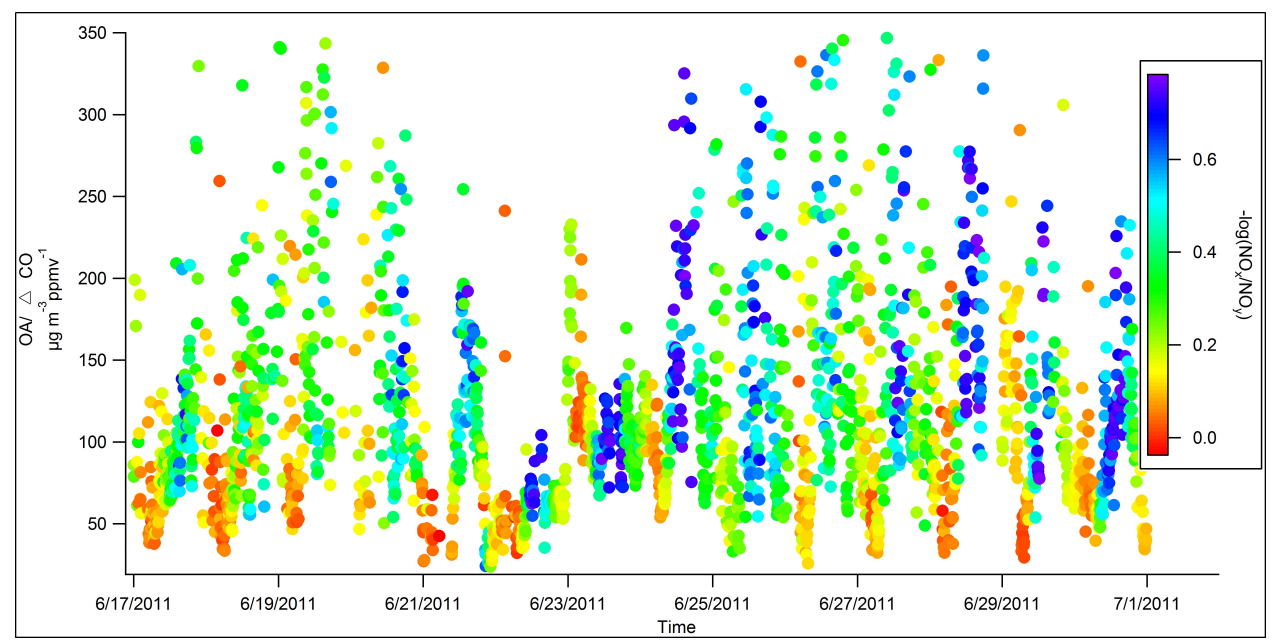




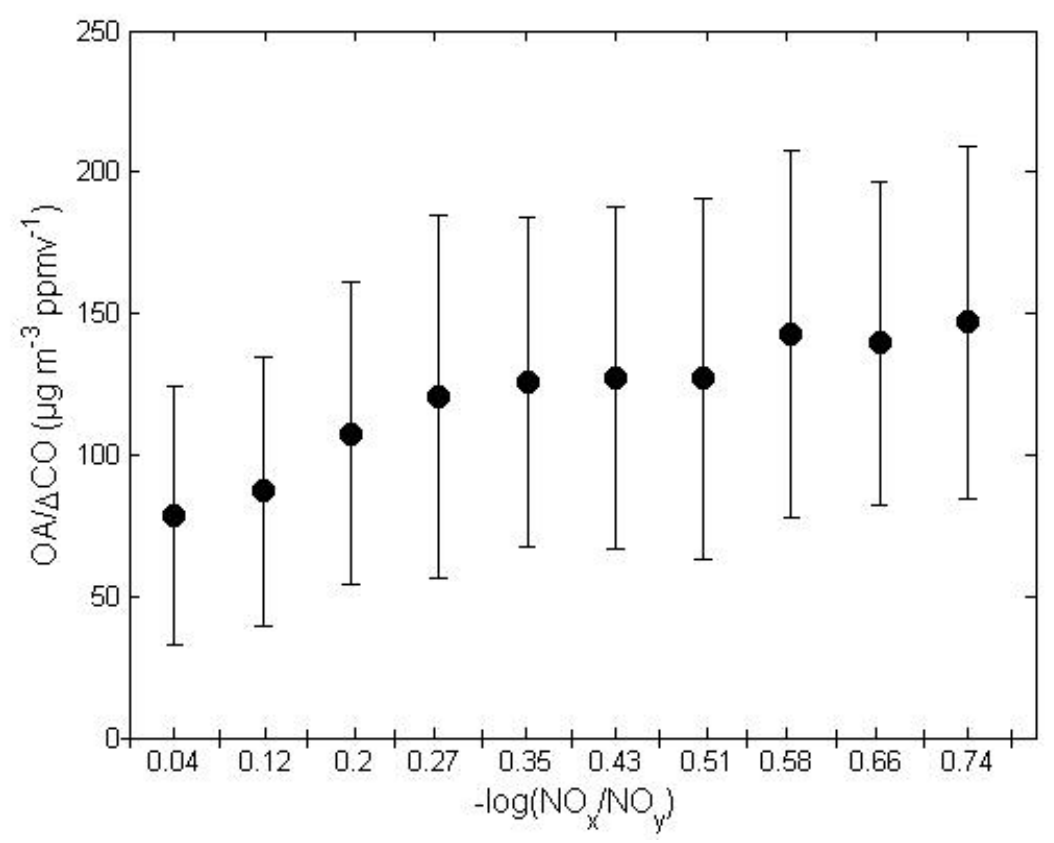

307 Figure 5. a.) $\mathrm{OA} / \Delta \mathrm{CO}\left(\mu \mathrm{g} \mathrm{m}^{-3} \mathrm{ppmv}^{-1}\right)$ ratios color coded by $-\log \left(\mathrm{NO}_{\mathrm{x}} / \mathrm{NO}_{\mathrm{y}}\right)$ b.) $\mathrm{OA} / \Delta \mathrm{CO}\left(\mu \mathrm{g} \mathrm{m}^{-3} \mathrm{ppmv}^{-1}\right)$ vs. $\log \left(\mathrm{NO}_{\mathrm{x}} / \mathrm{NO}_{\mathrm{y}}\right)$. The measured ratios $\mathrm{OA} / \Delta \mathrm{CO}$ are averaged into 10 bins according to $-\log \left(\mathrm{NO}_{\mathrm{x}} / \mathrm{NO}_{\mathrm{y}}\right)$. Error bars show the range of data.

\subsubsection{Photochemical Age}

Photochemical age, $\Delta \mathrm{t}$, with respect to hydrocarbons (toluene and benzene) is estimated as

313 (Roberts et al., 1984).

$315 \Delta \mathrm{t}=\frac{1}{[\mathrm{OH}](k \mathrm{t}-k \mathrm{~b})} \times\left[\ln \left(\frac{[\text { toluene }]}{[\text { benzene }]} \mid \mathrm{t}=0\right)-\ln \frac{[\text { toluene }]}{[\text { benzene }]}\right]$

317 where brackets represent mixing ratios (PTR-ToF-MS ambient measurements in ppb for toluene

318 and benzene) or number densities (for $\mathrm{OH}$, assumed for the entire data set to be $3 \times 10^{6}$ molecules

$319 \mathrm{~cm}^{-3}$ ) and $\mathrm{k}_{\mathrm{t}}$ and $\mathrm{k}_{\mathrm{b}}$ are the rate coefficients (not temperature-corrected) for the reaction of $\mathrm{OH}$

320 with toluene $\left(5.63 \times 10^{-12} \mathrm{~cm}^{3}\right.$ molecule $\left.\mathrm{s}^{-1}\right)$ and benzene $\left(1.22 \times 10^{-12} \mathrm{~cm}^{3}\right.$ molecule $\left.\mathrm{s}^{-1}\right)$,

321 respectively (Atkinson and Arey, 2003; de Gouw et al., 2005). The initial ratio of toluene to

322 benzene is assumed to be 1.4 based on Texas emission inventories (Zhou et al., 2012). 
323 Photochemical age values are zero when the toluene to benzene ratio is equal to that at the point

324 of emission. Toluene and benzene mixing ratios (Figure S7) during the campaign are shown in

325 the supplementary information.

326 Photochemical age values ranges between 13.9 and 38.1 hours. Table 1 shows the average

327 photochemical age was $26.7 \pm 5.3$ hours. The photochemical age range is similar but slightly

328 higher than values calculated by Cottrell et al. (2008) at Thompson Farm in semi-rural New

329 England, which is slightly further from a major metropolitan area, Hayes et al. (2013) in

330 Pasadena, CA, and $\mathrm{Hu}$ et al. (2013) in Changdao Island, China.

331 Figure 6 a shows the time series of $\mathrm{OA} / \Delta \mathrm{CO}$ colored as a function of photochemical age with

332 respect to the toluene to benzene (predominantly anthropogenic hydrocarbons) ratio. While a

333 decrease in $\mathrm{OA} / \Delta \mathrm{CO}$ ratio is observed between June 17 and 21, after June 21, a more

334 pronounced positive relation is observed (Figure 6a). As illustrated in Figure 6b, the positive

335 correlation between $\mathrm{OA} / \Delta \mathrm{CO}$ and the photochemical age is valid only up to approximately 30

336 hours, after which $\mathrm{OA} / \triangle \mathrm{CO}$ decreases with age. This could indicate dilution by fresh airmasses

337 high in CO. It also could mark a point where further aging leads to a decrease in OA, as has

338 been suggested by Murphy et al. (2012) and observed in an aging of emissions within a tunnel

339 (Tkacik et al., 2014). Their hypothesis is that fragmentation (as opposed to functionalization) of

340 organic molecules will lead to their repartitioning to the gas phase. Rapid enhancement of OA

341 over excess CO on the time scale of one day and a slower OA enhancement after a one-day

342 period have been observed in other studies such as the New England Air Quality Study in 2002

343 (de Gouw et al., 2005) and the MILAGRO field campaign in Mexico City in 2006 (DeCarlo et

344 al., 2010). However, those studies did not indicate the peak in the OA/ $\Delta C O$ ratio-photochemical

345 age relationship observed here. 

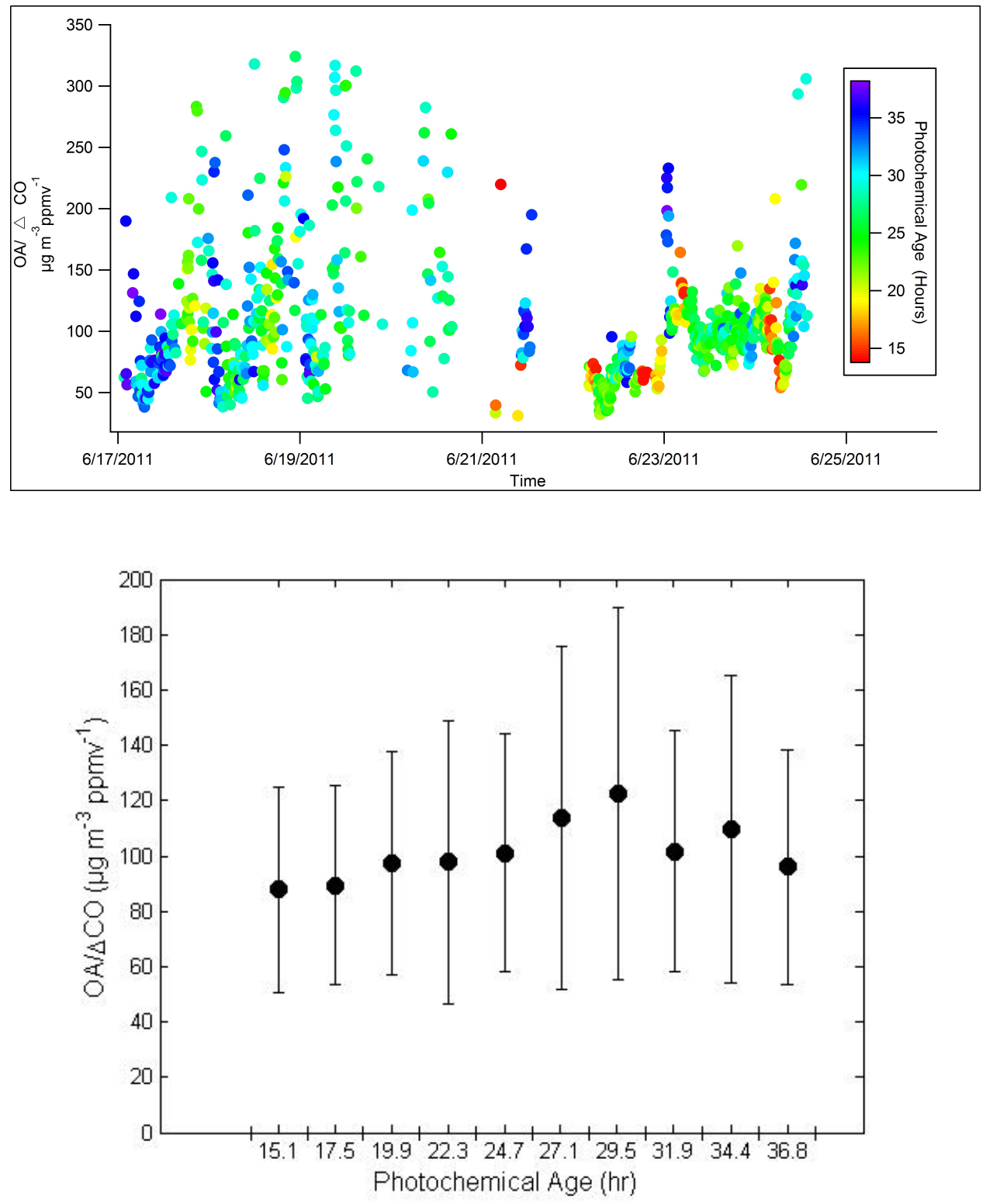

Figure 6. a.) $\mathrm{OA} / \Delta \mathrm{CO}\left(\mu \mathrm{g} \mathrm{m}^{-3} \mathrm{ppmv}^{-1}\right)$ ratios color coded by photochemical age (hr) b.) $\mathrm{OA} / \Delta \mathrm{CO}\left(\mu \mathrm{g} \mathrm{m}^{-3} \mathrm{ppmv}^{-1}\right)$ vs. photochemical age (hr). The measured ratios $\mathrm{OA} / \Delta \mathrm{CO}$ are averaged into 10 bins according to photochemical age. Error bars show the range of data.

\section{Conclusions}

The average aerosol composition in DFW was dominated by OA and sulfate. A detailed

354 analysis of OA concentrations shows a tight correlation with $\mathrm{CO}$. Elemental analysis indicates

355 the probable importance of carboxylic acid in OOA, but the wide range of OSc values observed suggests HOA also is important. The time series for $\mathrm{pSOA}, \mathrm{O}_{3}$, and $\mathrm{O}_{\mathrm{x}}$ track each other well and 
suggest photochemical SOA formation. Overall, a positive correlation can be observed between

$\mathrm{OA} / \Delta \mathrm{CO}$ values and $-\log \left(\mathrm{NO}_{\mathrm{x}} / \mathrm{NO}_{\mathrm{y}}\right)$. More rapid OA enhancement is observed with lower

values (between 0 and 0.3$)$ of $-\log \left(\mathrm{NO}_{\mathrm{x}} / \mathrm{NO}_{\mathrm{y}}\right)$, signifying $\mathrm{OA}$ processing and formation are more

rapid in fresher airmasses. Increasing $\mathrm{OA} / \Delta \mathrm{CO}$ with photochemical age is valid only up to

approximately 30 hours, after which $\mathrm{OA} / \Delta \mathrm{CO}$ decreases with age as a result of dilution or

362

reactions that decrease $\mathrm{OA}$. These aging-OA/ $\triangle \mathrm{CO}$ relationships warrant further investigation

and highlight that caution must be used when describing an airmass as "aged."

\section{Acknowledgements}

366

367

368

369

370

This study was supported by the TCEQ Air Quality Research Program. The authors would like to thank Melanie Calzada, Caroline Gutierrez, and Kabindra Shakya for help in data collection, the Texas National Guard for providing access to the site, Dr. Wei Zhou for provision of the Texas emission information, and Dr. Loren Raun for helpful discussions.

\section{References}

Aiken, A.C., DeCarlo, P.F., Kroll, J.H., Worsnop, D.R., Huffman, J.A., Docherty, K.S., Ulbrich, I.M., Mohr, C., Kimmel, J.R., Sueper, D., Sun, Y., Zhang, Q., Trimborn, A., Northway, M., Ziemann, P.J., Canagaratna, M.R., Onasch, T.B., Alfarra, M.R., Prevot, A.S.H., Dommen, J., Duplissy, J., Metzger, A., Baltensperger, U. \& Jimenez, J.L. (2008) O/C and $\mathrm{OM} / \mathrm{OC}$ Ratios of Primary, Secondary, and Ambient Organic Aerosols with HighResolution Time-of-Flight Aerosol Mass Spectrometry. Environ. Sci. Technol., 42, 44784485 .

Atkinson, R. \& Arey, J. (2003) Atmospheric degradation of volatile organic compounds. Chemical Reviews, 103, 4605-4638.

Cabada, J.C., Pandis, S.N., Subramanian, R., Robinson, A.L., Polidori, A. \& Turpin, B. (2004) Estimating the Secondary Organic Aerosol Contribution to PM2.5 Using the EC Tracer Method Special Issue of Aerosol Science and Technology on Findings from the Fine Particulate Matter Supersites Program. Aerosol Science and Technology, 38, 140-155. 
Cleveland, M.J., Ziemba, L.D., Griffin, R.J., Dibb, J.E., Anderson, C.H., Lefer, B. \& Rappenglück, B. (2012) Characterization of urban aerosol using aerosol mass spectrometry and proton nuclear magnetic resonance spectroscopy. Atmospheric Environment, 54, 511-518.

Cottrell, L.D., Griffin, R.J., Jimenez, J.L., Zhang, Q., Ulbrich, I., Ziemba, L.D., Beckman, P.J., Sive, B.C. \& Talbot, R.W. (2008) Submicron particles at Thompson Farm during ICARTT measured using aerosol mass spectrometry. Journal of Geophysical Research: Atmospheres, 113, D08212.

de Gouw, J.A., Middlebrook, A.M., Warneke, C., Goldan, P.D., Kuster, W.C., Roberts, J.M., Fehsenfeld, F.C., Worsnop, D.R., Canagaratna, M.R., Pszenny, A.A.P., Keene, W.C., Marchewka, M., Bertman, S.B. \& Bates, T.S. (2005) Budget of organic carbon in a polluted atmosphere: Results from the New England Air Quality Study in 2002. Journal of Geophysical Research: Atmospheres, 110, D16305.

DeCarlo, P.F., Dunlea, E.J., Kimmel, J.R., Aiken, A.C., Sueper, D., Crounse, J., Wennberg, P.O., Emmons, L., Shinozuka, Y., Clarke, A., Zhou, J., Tomlinson, J., Collins, D.R., Knapp, D., Weinheimer, A.J., Montzka, D.D., Campos, T. \& Jimenez, J.L. (2008) Fast airborne aerosol size and chemistry measurements above Mexico City and Central Mexico during the MILAGRO campaign. Atmos. Chem. Phys., 8, 4027-4048.

DeCarlo, P.F., Kimmel, J.R., Trimborn, A., Northway, M.J., Jayne, J.T., Aiken, A.C., Gonin, M., Fuhrer, K., Horvath, T., Docherty, K.S., Worsnop, D.R. \& Jimenez, J.L. (2006) Fielddeployable, high-resolution, time-of-flight aerosol mass spectrometer. Anal Chem, 78, 8281-8289.

DeCarlo, P.F., Ulbrich, I.M., Crounse, J., de Foy, B., Dunlea, E.J., Aiken, A.C., Knapp, D., Weinheimer, A.J., Campos, T., Wennberg, P.O. \& Jimenez, J.L. (2010) Investigation of the sources and processing of organic aerosol over the Central Mexican Plateau from aircraft measurements during MILAGRO. Atmos. Chem. Phys., 10, 5257-5280.

Forster, P., Ramaswamy, V., Artaxo, P., Berntsen, T., Betts, R., Fahey, D.W., Haywood, J., Lean, J., Lowe, D.C., Myhre, G., Nganga, J., Prinn, R., Raga, G., Schulz, M. \& Van Dorland, R. (2007) Changes in Atmospheric Constituents and in Radiative Forcing. In: Climate Change 2007: The Physical Science Basis. Contribution of Working Group I to the Fourth Assessment Report of the Intergovernmental Panel on Climate Change [Solomon, S., D. Qin, M. Manning, Z. Chen, M. Marquis, K.B. Averyt, M.Tignor and H.L. Miller (eds.)]. 
Hayden, K.L., Sills, D.M.L., Brook, J.R., Li, S.M., Makar, P.A., Markovic, M.Z., Liu, P., Anlauf, K.G., O'Brien, J.M., Li, Q. \& McLaren, R. (2011) Aircraft study of the impact of lake-breeze circulations on trace gases and particles during BAQS-Met 2007. Atmos. Chem. Phys. Discuss., 11, 11497-11546.

Hayes, P.L., Ortega, A.M., Cubison, M.J., Froyd, K.D., Zhao, Y., Cliff, S.S., Hu, W.W., Toohey, D.W., Flynn, J.H., Lefer, B.L., Grossberg, N., Alvarez, S., Rappenglück, B., Taylor, J.W., Allan, J.D., Holloway, J.S., Gilman, J.B., Kuster, W.C., de Gouw, J.A., Massoli, P., Zhang, X., Liu, J., Weber, R.J., Corrigan, A.L., Russell, L.M., Isaacman, G., Worton, D.R., Kreisberg, N.M., Goldstein, A.H., Thalman, R., Waxman, E.M., Volkamer, R., Lin, Y.H., Surratt, J.D., Kleindienst, T.E., Offenberg, J.H., Dusanter, S., Griffith, S., Stevens, P.S., Brioude, J., Angevine, W.M. \& Jimenez, J.L. (2013) Organic aerosol composition and sources in Pasadena, California, during the 2010 CalNex campaign. Journal of Geophysical Research: Atmospheres, 118, 9233-9257.

Heald, C.L., Kroll, J.H., Jimenez, J.L., Docherty, K.S., DeCarlo, P.F., Aiken, A.C., Chen, Q., Martin, S.T., Farmer, D.K. \& Artaxo, P. (2010) A simplified description of the evolution of organic aerosol composition in the atmosphere. Geophysical Research Letters, 37, L08803.

Herndon, S.C., Onasch, T.B., Wood, E.C., Kroll, J.H., Canagaratna, M.R., Jayne, J.T., Zavala, M.A., Knighton, W.B., Mazzoleni, C., Dubey, M.K., Ulbrich, I.M., Jimenez, J.L., Seila, R., de Gouw, J.A., de Foy, B., Fast, J., Molina, L.T., Kolb, C.E. \& Worsnop, D.R. (2008) Correlation of secondary organic aerosol with odd oxygen in Mexico City. Geophysical Research Letters, 35, L15804.

Hodzic, A. \& Jimenez, J.L. (2011) Modeling anthropogenically controlled secondary organic aerosols in a megacity: a simplified framework for global and climate models. Geosci. Model Dev., 4, 901-917.

Hu, W.W., Hu, M., Yuan, B., Jimenez, J.L., Tang, Q., Peng, J.F., Hu, W., Shao, M., Wang, M., Zeng, L.M., Wu, Y.S., Gong, Z.H., Huang, X.F. \& He, L.Y. (2013) Insights on organic aerosol aging and the influence of coal combustion at a regional receptor site of Central Eastern China. Atmos. Chem. Phys. Discuss., 13, 10809-10858.

Huang, X.F., He, L.Y., Hu, M., Canagaratna, M.R., Sun, Y., Zhang, Q., Zhu, T., Xue, L., Zeng, L.W., Liu, X.G., Zhang, Y.H., Jayne, J.T., Ng, N.L. \& Worsnop, D.R. (2010) Highly time-resolved chemical characterization of atmospheric submicron particles during 2008 Beijing Olympic Games using an Aerodyne High-Resolution Aerosol Mass Spectrometer. Atmos. Chem. Phys., 10, 8933-8945. 
Jimenez, J.L., Canagaratna, M.R., Donahue, N.M., Prevot, A.S.H., Zhang, Q., Kroll, J.H., DeCarlo, P.F., Allan, J.D., Coe, H., Ng, N.L., Aiken, A.C., Docherty, K.S., Ulbrich, I.M., Grieshop, A.P., Robinson, A.L., Duplissy, J., Smith, J.D., Wilson, K.R., Lanz, V.A., Hueglin, C., Sun, Y.L., Tian, J., Laaksonen, A., Raatikainen, T., Rautiainen, J., Vaattovaara, P., Ehn, M., Kulmala, M., Tomlinson, J.M., Collins, D.R., Cubison, M.J., E., Dunlea, J., Huffman, J.A., Onasch, T.B., Alfarra, M.R., Williams, P.I., Bower, K., Kondo, Y., Schneider, J., Drewnick, F., Borrmann, S., Weimer, S., Demerjian, K., Salcedo, D., Cottrell, L., Griffin, R., Takami, A., Miyoshi, T., Hatakeyama, S., Shimono, A., Sun, J.Y., Zhang, Y.M., Dzepina, K., Kimmel, J.R., Sueper, D., Jayne, J.T., Herndon, S.C., Trimborn, A.M., Williams, L.R., Wood, E.C., Middlebrook, A.M., Kolb, C.E., Baltensperger, U. \& Worsnop, D.R. (2009) Evolution of Organic Aerosols in the Atmosphere. Science, 326, 1525-1529.

Kleinman, L.I., Daum, P.H., Lee, Y.-N., Senum, G.I., Springston, S.R., Wang, J., Berkowitz, C., Hubbe, J., Zaveri, R.A., Brechtel, F.J., Jayne, J., Onasch, T.B. \& Worsnop, D. (2007) Aircraft observations of aerosol composition and ageing in New England and MidAtlantic States during the summer 2002 New England Air Quality Study field campaign. Journal of Geophysical Research: Atmospheres, 112, D09310.

Kleinman, L.I., Springston, S.R., Daum, P.H., Lee, Y.N., Nunnermacker, L.J., Senum, G.I., Wang, J., Weinstein-Lloyd, J., Alexander, M.L., Hubbe, J., Ortega, J., Canagaratna, M.R. \& Jayne, J. (2008) The time evolution of aerosol composition over the Mexico City plateau. Atmos. Chem. Phys., 8, 1559-1575.

Kroll, J.H., Donahue, N.M., Jimenez, J.L., Kessler, S.H., Canagaratna, M.R., Wilson, K.R., Altieri, K.E., Mazzoleni, L.R., Wozniak, A.S., Bluhm, H., Mysak, E.R., Smith, J.D., Kolb, C.E. \& Worsnop, D.R. (2011) Carbon oxidation state as a metric for describing the chemistry of atmospheric organic aerosol. Nat. Chem., 3, 133-139.

Liu, S., Day, D.A., Shields, J.E. \& Russell, L.M. (2011) Ozone-driven daytime formation of secondary organic aerosol containing carboxylic acid groups and alkane groups. Atmos. Chem. Phys., 11, 8321-8341.

Murphy, B.N., Donahue, N.M., Fountoukis, C., Dall'Osto, M., O'Dowd, C., Kiendler-Scharr, A. \& Pandis, S.N. (2012) Functionalization and fragmentation during ambient organic aerosol aging: application of the 2-D volatility basis set to field studies. Atmos. Chem. Phys., 12, 10797-10816.

Orsini, D.A., Ma, Y., Sullivan, A., Sierau, B., Baumann, K. \& Weber, R.J. (2003) Refinements to the particle-into-liquid sampler (PILS) for ground and airborne measurements of water soluble aerosol composition. Atmospheric Environment, 37, 1243-1259. 
Pope, C.A., 3rd, Burnett, R.T., Thun, M.J., Calle, E.E., Krewski, D., Ito, K. \& Thurston, G.D. (2002) Lung cancer, cardiopulmonary mortality, and long-term exposure to fine particulate air pollution. Jama, 287, 1132-1141.

514

515

516

517

Quinn, P.K., Bates, T.S., Baynard, T., Clarke, A.D., Onasch, T.B., Wang, W., Rood, M.J., Andrews, E., Allan, J., Carrico, C.M., Coffman, D. \& Worsnop, D. (2005) Impact of particulate organic matter on the relative humidity dependence of light scattering: A simplified parameterization. Geophysical Research Letters, 32, L22809.

Roberts, J.M., C., F.F., C., L.S., J., B.M., C., H., L., A.D. \& E., S.R. (1984) Measurements of aromatic hydrocarbon ratios and NOx concentrations in the rural troposphere: Estimates of air mass photochemical age and NOx removal rate. Atmos. Environ, 18, 2421 - 2432.

Slowik, J.G., Brook, J., Chang, R.Y.W., Evans, G.J., Hayden, K., Jeong, C.H., Li, S.M., Liggio, J., Liu, P.S.K., McGuire, M., Mihele, C., Sjostedt, S., Vlasenko, A. \& Abbatt, J.P.D. (2011) Photochemical processing of organic aerosol at nearby continental sites: contrast between urban plumes and regional aerosol. Atmos. Chem. Phys., 11, 2991-3006.

Springston, S.R., Kleinman, L.I., Brechtel, F., Lee, Y.-N., Nunnermacker, L.J. \& Wang, J. (2005) Chemical evolution of an isolated power plant plume during the TexAQS 2000 study. Atmospheric Environment, 39, 3431-3443.

Tkacik, D.S., Lambe, A.T., Jathar, S., Li, X., Presto, A.A., Zhao, Y.L., Blake, D., Meinardi, S., Jayne, J.T., Croteau, P.L. \& Robinson, A.L. (2014) Secondary Organic Aerosol Formation from in-Use Motor Vehicle Emissions Using a Potential Aerosol Mass Reactor. Environ. Sci. Technol., 48, 11235-11242.

Ulbrich, I.M., Canagaratna, M.R., Zhang, Q., Worsnop, D.R. \& Jimenez, J.L. (2009) Interpretation of organic components from Positive Matrix Factorization of aerosol mass spectrometric data. Atmos. Chem. Phys., 9, 2891-2918.

Weber, R.J., Orsini, D., Daun, Y., Lee, Y.N., Klotz, P.J. \& Brechtel, F. (2001) A Particle-intoLiquid Collector for Rapid Measurement of Aerosol Bulk Chemical Composition. Aerosol Science and Technology, 35, 718-727.

Wojcik, G.S. \& Chang, J.S. (1997) A Re-Evaluation of Sulfur Budgets, Lifetimes, and Scavenging Ratios for Eastern North America. Journal of Atmospheric Chemistry, 26, 109-145. 
Wood, E.C., Canagaratna, M.R., Herndon, S.C., Kroll, J.H., Onasch, T.B., Kolb, C.E., Worsnop, D.R., Knighton, W.B., Seila, R., Zavala, M., Molina, L.T., DeCarlo, P.F., Jimenez, J.L., Weinheimer, A.J., Knapp, D.J., Jobson, B.T., Stutz, J., Kuster, W.C. \& Williams, E.J. (2010) Investigation of the correlation between odd oxygen and secondary organic aerosol in Mexico City and Houston. Atmos. Chem. Phys. Discuss., 10, 3547-3604.

Zhang, Q., Jimenez, J.L., Canagaratna, M.R., Allan, J.D., Coe, H., Ulbrich, I., Alfarra, M.R., Takami, A., Middlebrook, A.M., Sun, Y.L., Dzepina, K., Dunlea, E., Docherty, K., DeCarlo, P.F., Salcedo, D., Onasch, T., Jayne, J.T., Miyoshi, T., Shimono, A., Hatakeyama, S., Takegawa, N., Kondo, Y., Schneider, J., Drewnick, F., Borrmann, S., Weimer, S., Demerjian, K., Williams, P., Bower, K., Bahreini, R., Cottrell, L., Griffin, R.J., Rautiainen, J., Sun, J.Y., Zhang, Y.M. \& Worsnop, D.R. (2007) Ubiquity and dominance of oxygenated species in organic aerosols in anthropogenically-influenced Northern Hemisphere midlatitudes. Geophysical Research Letters, 34, L13801.

Zhou, W., Cohan, D.S., Pinder, R.W., Neuman, J.A., Holloway, J.S., Peischl, J., Ryerson, T.B., Nowak, J.B., Flocke, F. \& Zheng, W.G. (2012) Observation and modeling of the evolution of Texas power plant plumes. Atmos. Chem. Phys., 12, 455-468. 


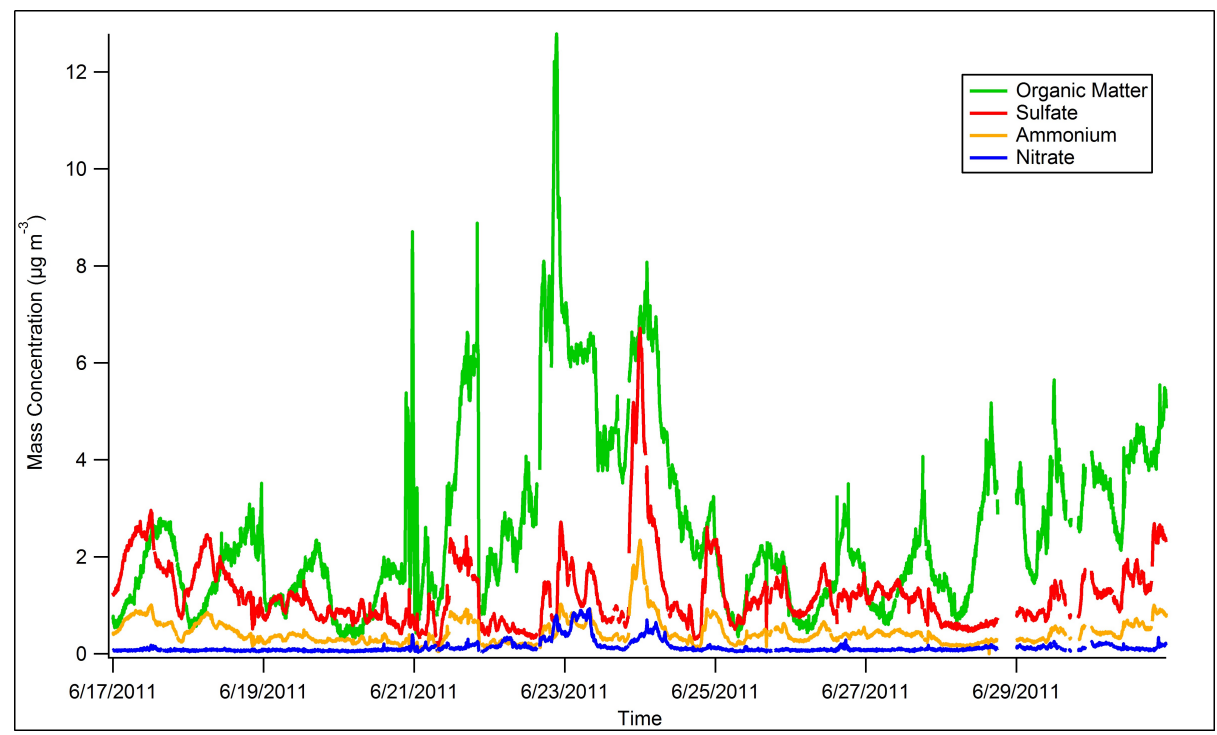

577 Figure S1. Time series of organic matter (green), $\mathrm{SO}_{4}{ }^{2-}$ (red), $\mathrm{NH}_{4}{ }^{+}$(orange), and $\mathrm{NO}_{3}^{-}$(blue)

578 mass concentrations $\left(\mu \mathrm{g} \mathrm{m}^{-3}\right)$. Chloride is not included due to its very small concentrations.

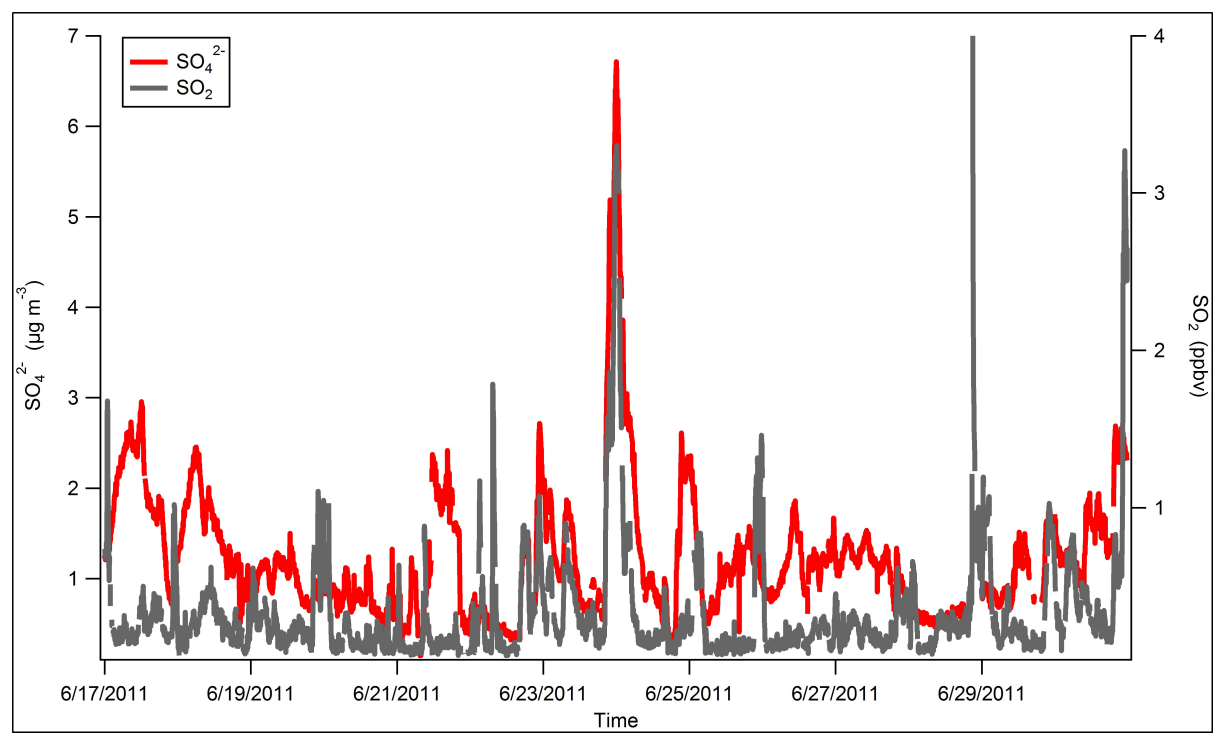

581 Figure S2. Time series of $\mathrm{SO}_{2}$ mixing ratios (gray, ppbv) and $\mathrm{SO}_{4}{ }^{2-}$ mass concentrations (red, $\mu \mathrm{g}$ $\left.582 \mathrm{~m}^{-3}\right)$. 


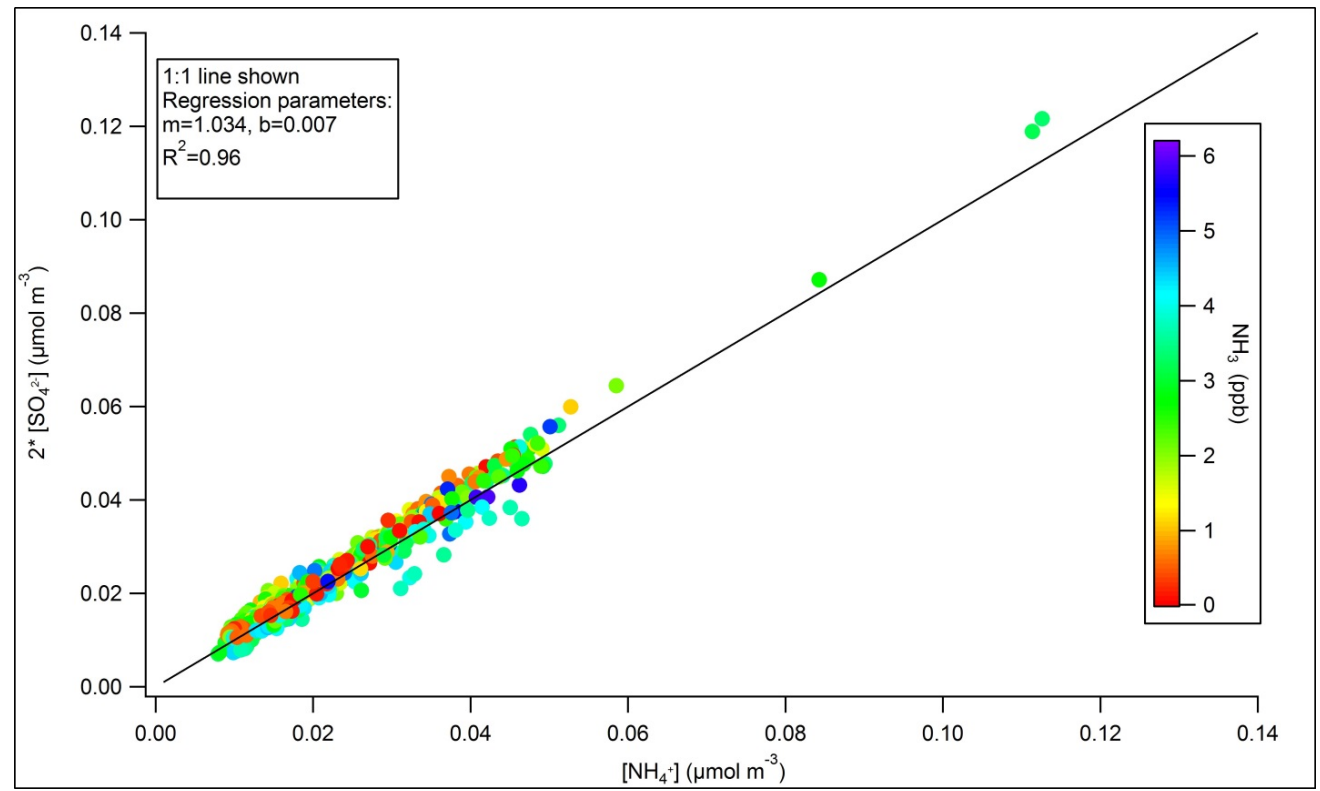

585 Figure S3. Scatter plot of $2 *\left[\mathrm{SO}_{4}{ }^{2-}\right]\left(\mu \mathrm{mol} \mathrm{m}{ }^{-3}\right)$ versus $\left[\mathrm{NH}_{4}{ }^{+}\right]\left(\mu \mathrm{mol} \mathrm{m}{ }^{-3}\right)$ color coded by $\mathrm{NH}_{3}$ $586(\mathrm{ppb})$.

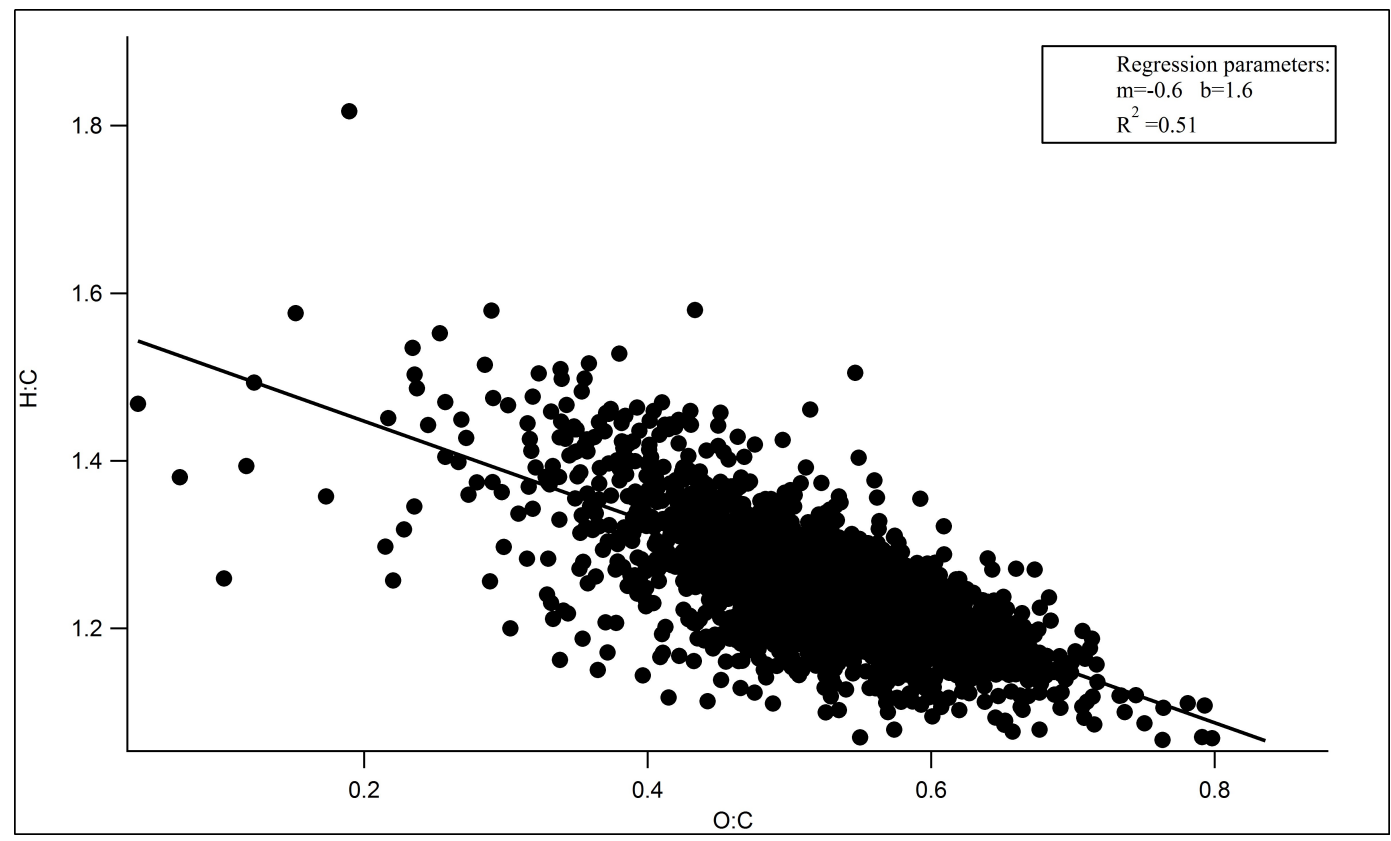

589 Figure S4. Van Krevelen diagram of elemental ratios (O:C vs. H:C) estimated from HR-ToF-

590 AMS measurements of OA. 


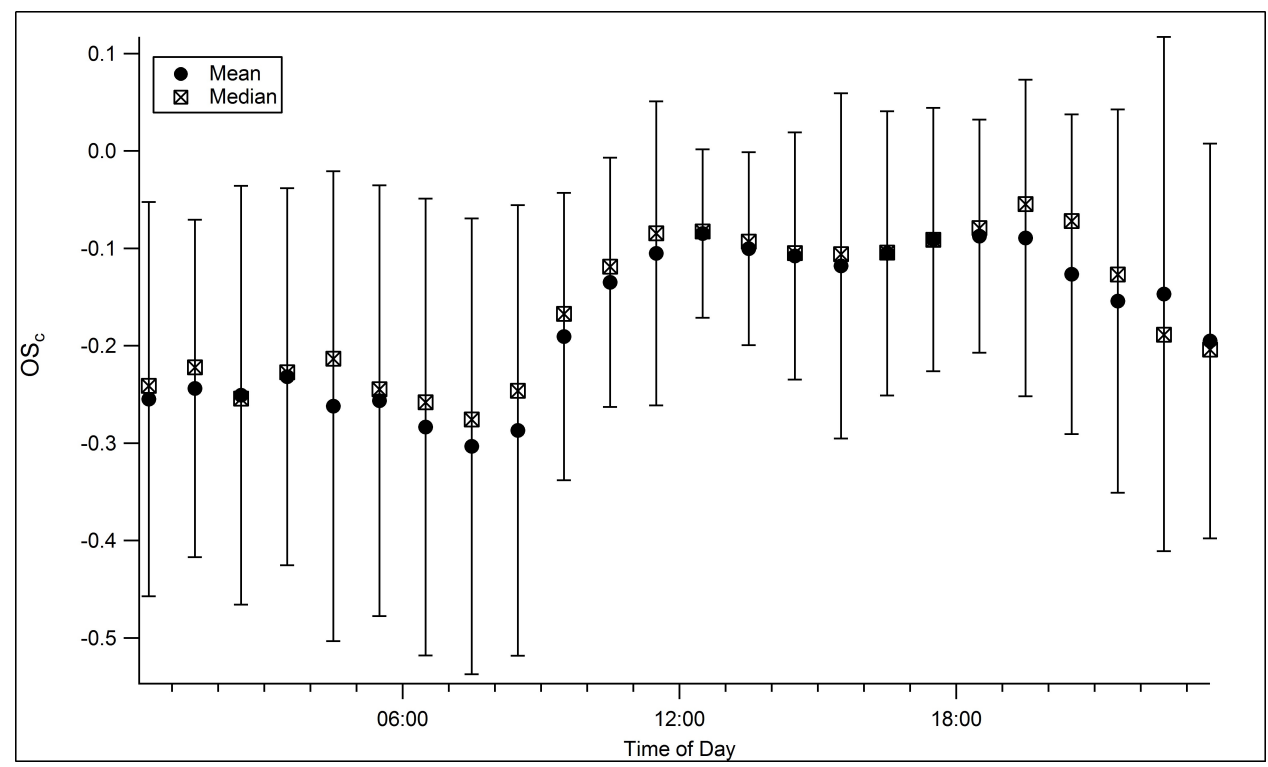

592 Figure S5. Diurnal profile of OSc, with formatting as described in Figure 1.

\section{Uncertainty Analysis}

The upper-lower bound method was used to estimate the maximum uncertainties in

$596 \mathrm{OA} / \triangle \mathrm{CO}$ and age metrics. Analytical uncertainties of relevant measurements and estimated

597 maximum uncertainties of $\mathrm{OA} / \Delta \mathrm{CO}, \mathrm{SO}_{4}{ }^{2-} /\left(\mathrm{SO}_{4}{ }^{2-}+\mathrm{SO}_{2}\right),-\log \left(\mathrm{NO}_{\mathrm{x}} / \mathrm{NO}_{\mathrm{y}}\right)$ and photochemical 598 age are summarized in Table S1. Differences in diurnal profiles and in the comparisons shown 599 in Figures 4b, 5b, and 6b were evaluated using a student's t-test; results supported statistical 600 differences from hour to hour in diurnal profile and in the relationships shown in Figures $5 \mathrm{~b}$ and $6016 b$. 
Table S1. Analytical uncertainties in relevant measurements and estimated uncertainties

604 in $\mathrm{OA} / \Delta \mathrm{CO}, \mathrm{SO}_{4}{ }^{2-} /\left(\mathrm{SO}_{4}{ }^{2-}+\mathrm{SO}_{2}\right),-\log \left(\mathrm{NO}_{\mathrm{x}} / \mathrm{NO}_{\mathrm{y}}\right)$ and photochemical age.

\begin{tabular}{|c|c|c|c|}
\hline Measurements & $\begin{array}{l}\text { Analytical } \\
\text { Uncertainty }\end{array}$ & $\begin{array}{c}\mathrm{OA} / \Delta \mathrm{CO} \text { and Age } \\
\text { Metrics }\end{array}$ & $\begin{array}{l}\text { Estimated } \\
\text { Uncertainty }\end{array}$ \\
\hline $\begin{array}{l}\mathrm{OA} \\
\mathrm{CO}\end{array}$ & $5 \%$ & $\mathrm{OA} / \Delta \mathrm{CO}$ & $15 \%$ \\
\hline $\begin{array}{c}\mathrm{SO}_{2} \\
\mathrm{SO}_{4}{ }^{2-}\end{array}$ & $8 \%$ & $\mathrm{SO}_{4}{ }^{2-} /\left(\mathrm{SO}_{4}{ }^{2-}+\mathrm{SO}_{2}\right)$ & $6 \%$ \\
\hline NO & $5 \%$ & & \\
\hline $\mathrm{NO}_{2}$ & $7 \%$ & $-\log \left(\mathrm{NO}_{\mathrm{x}} / \mathrm{NO}_{\mathrm{y}}\right)$ & $24 \%$ \\
\hline $\mathrm{NO}_{\mathrm{y}}$ & $5 \%$ & & \\
\hline Benzene & $\begin{array}{l}15 \% \\
\text { (Kim et al., 2015) }\end{array}$ & Photochemical Age & $26 \%$ \\
\hline
\end{tabular}




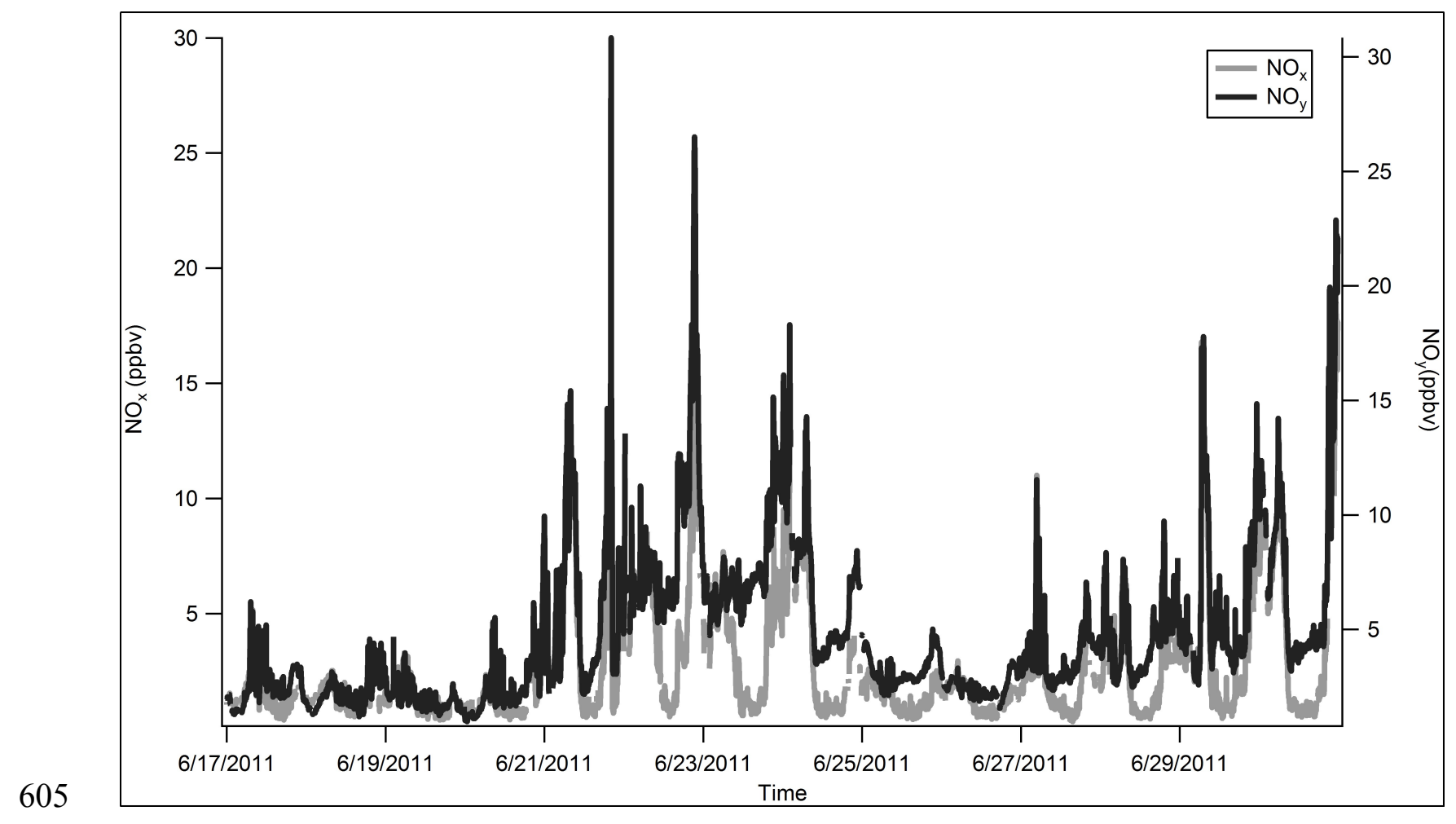

606 Figure S6. Time series of $\mathrm{NO}_{\mathrm{x}}$ (gray) and $\mathrm{NO}_{\mathrm{y}}$ (black) mixing ratios (ppbv).

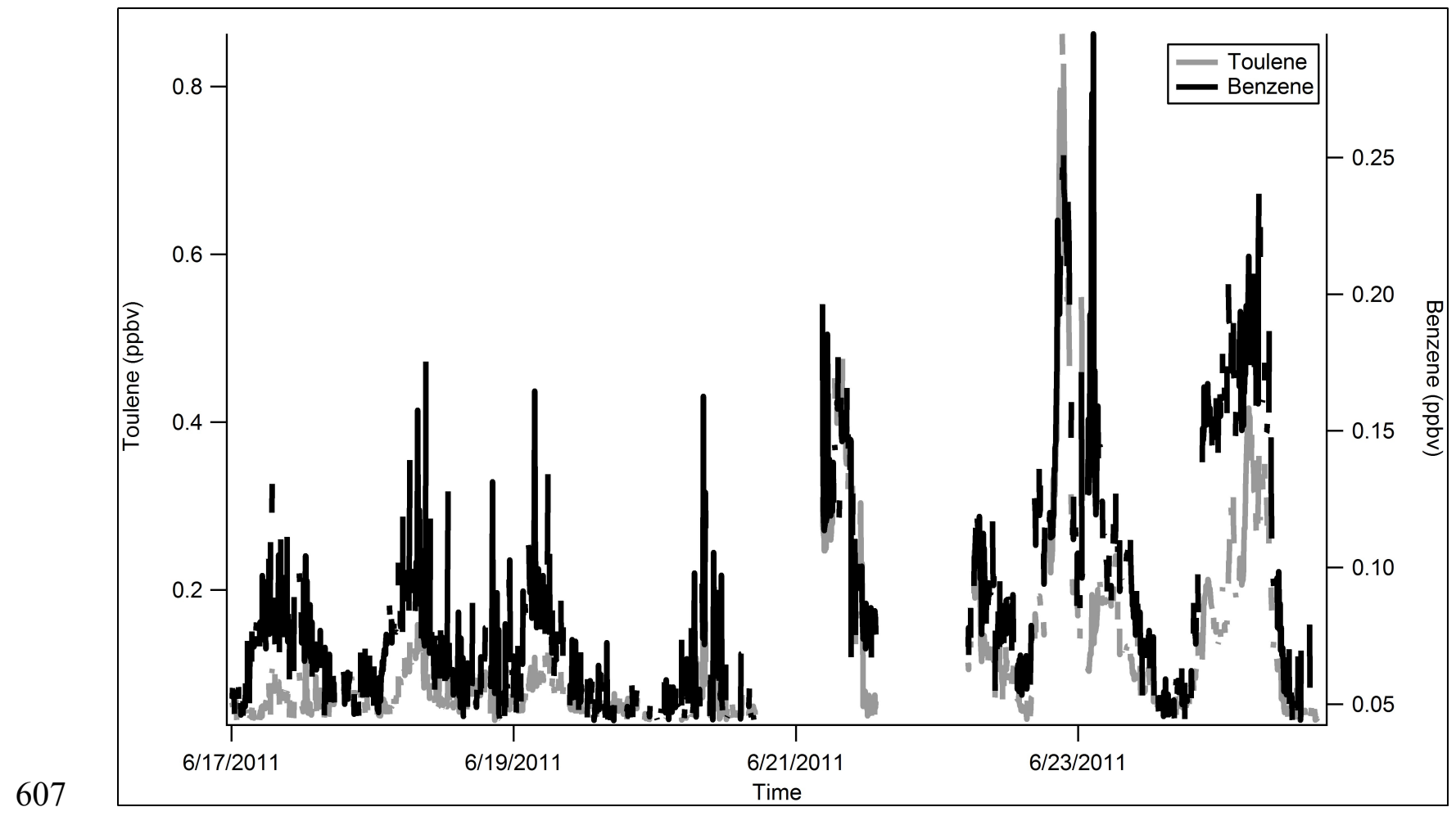

608 Figure S7. Time series of toluene (gray) and benzene (black) mixing ratios (ppbv). 
609 Kim, S., Guenther, A., Lefer, B., Flynn, J., Griffin, R., Rutter, A.P., Gong, L. \& Cevik, B.K. 610 (2015) Potential Role of Stabilized Criegee Radicals in Sulfuric Acid Production in a High

611 Biogenic VOC Environment. Environmental Science and Technology 49, 3383-3391. 